\title{
sciendo
}

\section{THERMAL COMFORT CHARACTERISTIC OF 5 PATTERNS OF A PERSIAN GARDEN IN A HOT-ARID CLIMATE OF SHIRAZ, IRAN}

\author{
MORTEZA OJAGHLOU $^{1 *}$, MEHDI KHAKZAND $^{2}$ \\ ${ }^{1}$ Department of Architecture, Qazvin Branch, Islamic Azad University, Qazvin, Iran. \\ Mobile: +989127412739. \\ ${ }^{2}$ Associate professor of Landscape architecture, School of Architecture and environmental \\ design, Iran University of Science and Technology, Tehran, Iran, Tel: +98 2177240467 \\ *Corresponding author e-mail: Morteza.ojaqlu@gmail.com
}

Received: $19^{\text {st }}$ March 2019, Accepted: $5^{\text {th }}$ September 2019

\begin{abstract}
Thermal comfort in the open spaces is a significant parameter in public mentally and physically healthy. Increased hot days of cities because of the urban heat island is the common phenomenon in cities. This phenomenon effect cites quality by a different aspect such as air quality, Use of fossil fuels etc. therefore, cooling strategies in the urban and urban park's design is one of the important issues of the designers. Urban parks have a significant effect on heat stress mitigation. Persian garden is known for its microclimate effect on pedestrians, so different patterns of Persian garden is selected to be analyzed in terms of thermal comfort condition on the hottest day of summer so far in the dry hot climate of the Shiraz $\left(12^{\text {th }}\right.$ of July 1998 with the maximum $42^{\circ} \mathrm{C}$ Ta). In this paper 8 conditions are simulated by Envi-met3.1 to get environment data of these patterns and also the Rayman model is used to calculate the Physiological Equivalent Temperature (PET) as the proper thermal index for outdoor condition. The results demonstrate that alteration of Shortwave radiation both direct and diffuse conditions and mean radiant temperature are affected by both sky view factor and the orientation of the Persian garden. Pavilion location has an important effect in mitigation of the Tmrt by preventing the afternoon powerful sun rays through to the paths in the End.E-W pattern. Therefore, this pattern has a better condition of PET value than the others in Shiraz setting.
\end{abstract} Iran

Keywords: Outdoor thermal comfort, Persian garden patterns, Envi-met3.1, PET, Shiraz.

\section{INTRODUCTION}

The quality of life for people in urban areas is the result of interaction between people and their surrounding urban environment (Das, 2008; Chou et al., 2016). Environmental quality is an abstract concept resulting from both human and natural factors operating at different spatial scales. In urban areas, the micro-scale is comprised of individual buildings, streets, and trees. The quality of the urban environment is a complex and spatially variable parameter which is the upshot of interrelated factors including the urban heat island, the distribution of greenery, building density, geometry and air quality (Wong et al., 2007; Nichol, 2005; 
Ojaghlou M., Khakzand M.: Thermal comfort characteristic of 5 patterns of a Persian garden in a hot-arid climate of Shiraz. Iran

Byomkesh et al., 2012; Xia et al., 2014). The above-mentioned quality profoundly depends on the thermal comfort of public green spaces in an urban context. In this field, there are diverse attitudes regarding the definition of thermal comfort (ASHRAE Standard, 1966; Heijis, 1994; Benziger, 1979; Hensen, 1990; Limb, 1992; McIntyre, 1980; Olgyay, 1963; Givoni, 1998). Though in brief definition, thermal comfort can be defined as' that condition of mind which expresses satisfaction with the thermal environment' (ISO, 1984). Investigation of outdoor thermal comfort condition has started from 1980 but in recent years studies on outdoor comfort and urban microclimate have risen rapidly, due to increasing global temperature (Middel et al., 2014; Toparlar et al., 2015; Dimoudi et al., 2013; Maleki et al., 2013; Andreou, 2013; Salata et al., 2015; Kim \& Suh, 2016) consequently attention to the pedestrians' thermal comfort and its parameters in urban context has been investigated in great number of studies (Oke, 1987; Givoni, 1998; Tseliou et al., 2010; Herrmann \& Matzarakis, 2012; Chen, 2012; Cohen et al., 2013; Andreou, 2013; Taleghani et al., 2013). Green infrastructures in cities like urban parks and gardens have a significant role in mitigating UHI and developing the thermal comfort in both mental and physical conditions (Tsilini et al., 2015; La Rosa et al., 2013; Orsini et al., 2014; Müller \& Morimoto, 2016). The urban microclimate is affected by numerous factors such as geometry, water and humidity, vegetation, and thermal features of surfaces (Balafoutis et al., 1998; Setaih et al., 2013; Do et al., 2014). Persian traditional gardens in hot and arid climate of Iran make a comfortable thermal environment. According to the Iranian traditional architecture, Persian garden is completely responsive to its hard and rough environment (Naeema, 2006). Thermal comfort studies in landscape and urban designs require both climatology and bio-meteorology related tools (Dessi, 2002; Brown, 1995). In most of the thermal comfort studies in outdoor setting both climatology and bio-meteorology have been measured by physiologically equivalent temperature and also the universal thermal climate index. Although there are several studies in conceptual and symbolical aspects of Persian garden (Medghalchi et al., 2014; Ghodazi Soroush et al., 2013; Moghtader \& Yavari, 1998; Burckhardt, 1976; Benmanian, 2008), there are few studies in thermal and environmental aspect of Persian garden (Taghvaei et al., 2015). Modifications of the climatic parameters are the main function of Persian garden in the rough environment of the Persian deserts, consequently Thermal characteristic of Persian garden based on its 4 garden patterns will help the landscape designer to use this concept to create more comfortable environment consciously.

\section{Aim of the present study}

We tried to elucidate the questions through an analysis of stand water balance (Ambros, 1978; Joffre \& Rambal, 1993). The water balance model was based especially on the quantitative knowledge of aboveground and underground structure of large trees in floodplain forests (Vyskot 1976; Vasicek, 1980; Cermak, 1989, 1998) and their seasonal transpiration measured at the experimental site (Penka et al., 1979, 1983; Cermak et al., 1982, 1991, 1995). Stand water balance was calculated for a unit of stand area but was scaled down to the fraction of stand area that belongs to a single model tree and other components of the system of proportional sizes. Long-term measurements allowed comparison of the original situation at the time of regular floods with actual and theoretical situations occurring under contrasting water supply after ceasing of floods. 


\section{MATERIAL AND METHODS}

\section{Location, stand and the environmental conditions}

Generally, Persian gardens can be categorized as 3 types of rectangular patterns. In this paper, research is carried out on 3 traditional rectangular patterns in addition to Square pattern and also an ancient pattern of gardening called Pasargadae, to assess thermal comfort in a hot and arid climate of Shiraz.These patterns are taken from the study of Pirniya (1994), Soltan Zadeh (1999) and Ranjbar Kermani (2005), as indicated in Fig1. The study aims to investigate the thermal comfort of pedestrians in a different point of the paths (start, middle, and end of each path) of the Persian garden. In this regard, the hottest day (12.07.1998) of Shiraz as a reference date is considered for simulation by the ENVI-met3.1 model. This program simulated the microclimates' data (e.g. mean radiant temperature, air temperature, relative humidity, etc.) and the output was 'measured' in points at a $1.40 \mathrm{~m}$ height at different points of the paths of the garden. As the next step, output was imported into Rayman model (Matzarakis et al., 2007) to calculate the $\mathrm{PET}^{1}$ based on the $\mathrm{SVF}^{2}$ of the receptor points. The outdoor thermal comfort of the points will be discussed and compared further.

Fig. 1: The research method.

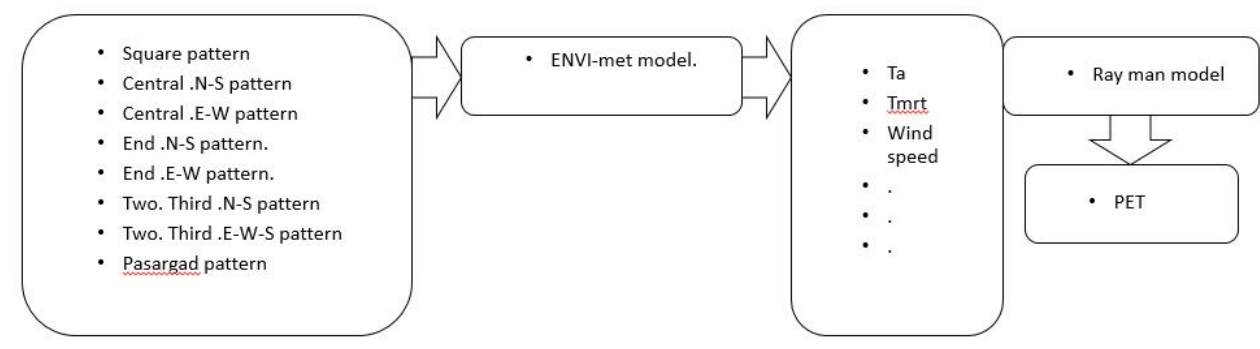

The geometries of Persian garden

The Geometry is the most prominent feature of a Persian garden. The quadripartite plan was the main concept of designing and forming the spaces in these gardens, from this viewpoint, Persian gardens follow the unique pattern in their location of components. These patterns are called Chahar Bagh (the four gardens). Most gardens have rectangular plans and have been divided into square or pseudo-square shapes, possibly, for the ease of determining the distance between garden components and the exact placement of greeneries (Mahmoudi Farahani et al., 2016). The main pavilion (KOSHK) of the garden was generally located in a different part of the gardens (Naeema, 2006) though; in general pattern, the pavilions are located in the main axis of the garden (according to the following Fig.2). Based on these categories, Ranjbar Kermani (2005) introduced 3 general patterns of gardening based on different locations of green spaces and pavilions. 


\section{Fig. 2: Four pavilion in Persian garden (Pirnia, 1994)}
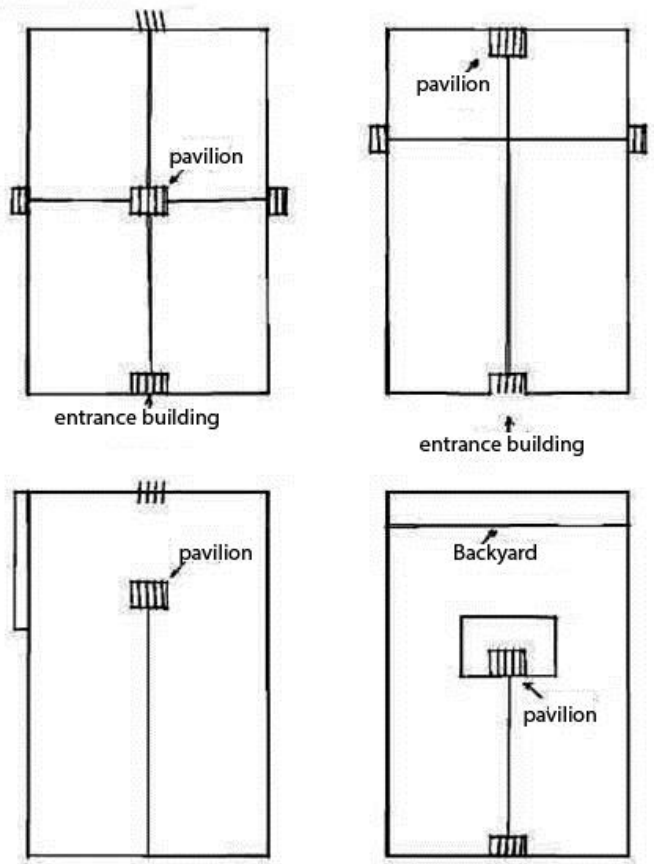

The first basic pattern

This is the basic and fundamental pattern of a Persian garden. In this form, the pavilion is positioned in the center of the garden, at the intersection of the main axes of the garden (Fig.3). The entrance building of the garden is across the main pavilion and on the main axis of the garden. This pattern is a general pattern of Persian gardening and one of the prominent examples is Taj Mahal in India. In Iran and also in Shiraz, Delgosha Garden can be mentioned of this ilk.

Fig. 3: Pattern 1 (Ranjbar Kermani, 2005)

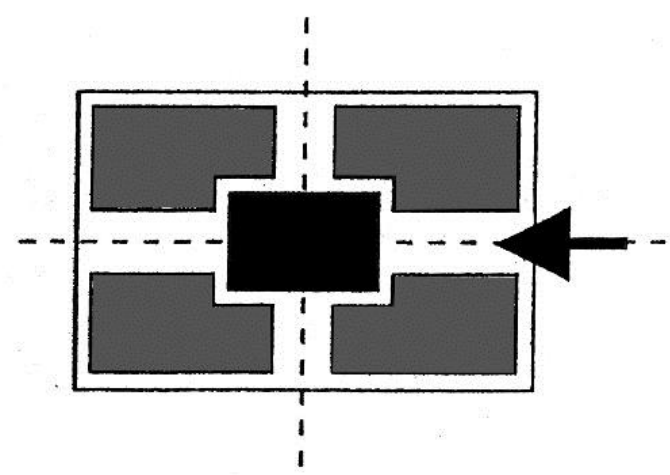




\section{The Second basic Pattern}

The second pattern of Persian gardening is the combination of the pavilion and the garden, in one-third of the main axis of the garden (Fig.4). Accordingly, if the length of the rectangular is divided into three-part, the pavilion is located in one-third of the longitudinal axes. Shahzadeh-e-Mahan garden in Kerman is the most famous example of this pattern. In Shiraz, Eram garden is the prominent instance of this kind of gardening.

\section{Fig. 4: Second pattern of Persian garden (Ranjbar Kermani, 2005)}

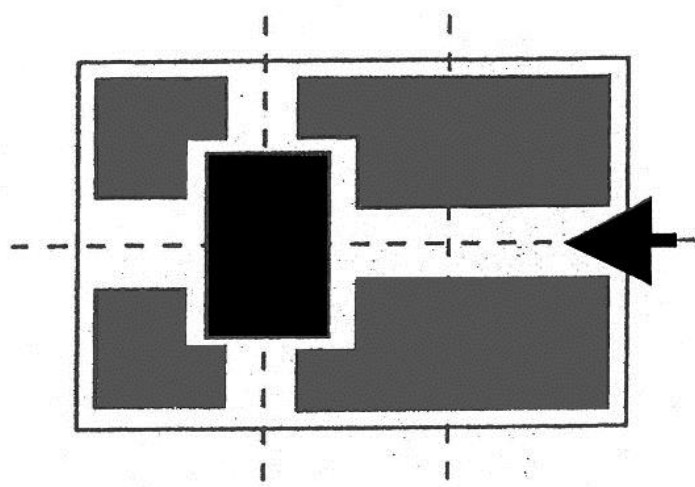

The Third basic pattern

This pattern emphasizes the main longitudinal axis of the garden (Fig.5). In this case, the pavilion is located at the end of the garden and it is close to the lateral side of the garden. Narejstan-e-Ghavam is a prominent instance of this pattern.

Fig. 5: The third pattern of Persian garden (Ranjbar Kermani, 2005)

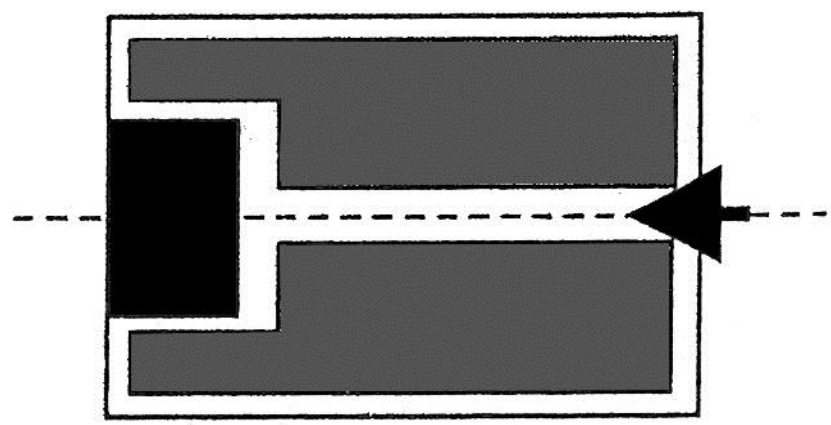

The Fourth pattern

In the three above-mentioned patterns, the predominant form was rectangular, but there are some other gardens in which the predominant form is square (Fig.6), in these gardens the pavilion is exactly in the center of the garden. Jahan Nama is a well-known example of this pattern. 
Ojaghlou M., Khakzand M.: Thermal comfort characteristic of 5 patterns of a Persian garden in a hot-arid climate of Shiraz. Iran

\section{Fig. 6: Square pattern of the Persian garden}

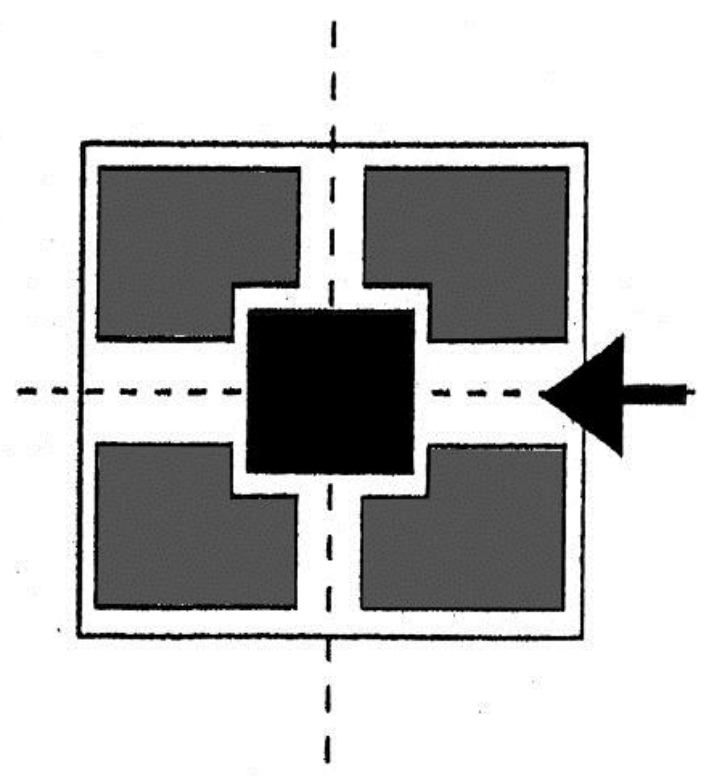

The Pasargadae

Persian garden designing has been an ongoing procedure since the ancient world (559-530 BC) to contemporary time (Fig.7). Pasargadae is the most famous and important garden in the ancient world. Pasargadae uniquely differs from other gardens in terms of its following the patterns of Chahar Bagh (the four gardens), so it makes it crucial to investigate the outdoor thermal characteristics of this garden. To illustrate the points further, the most prominent examples of each pattern are provided in the following Fig. 8.

Fig. 7: Pasargadae garden. According to David Stronach model (1978)
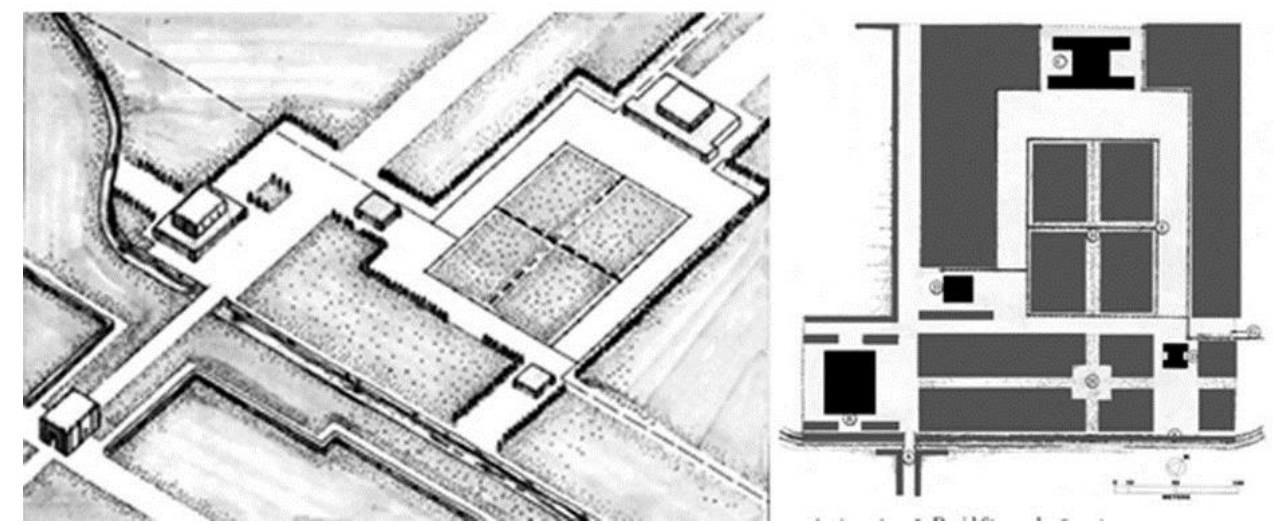
Fig. 8: Aerial view of Shiraz and selected gardens (maps. Google, 2016)

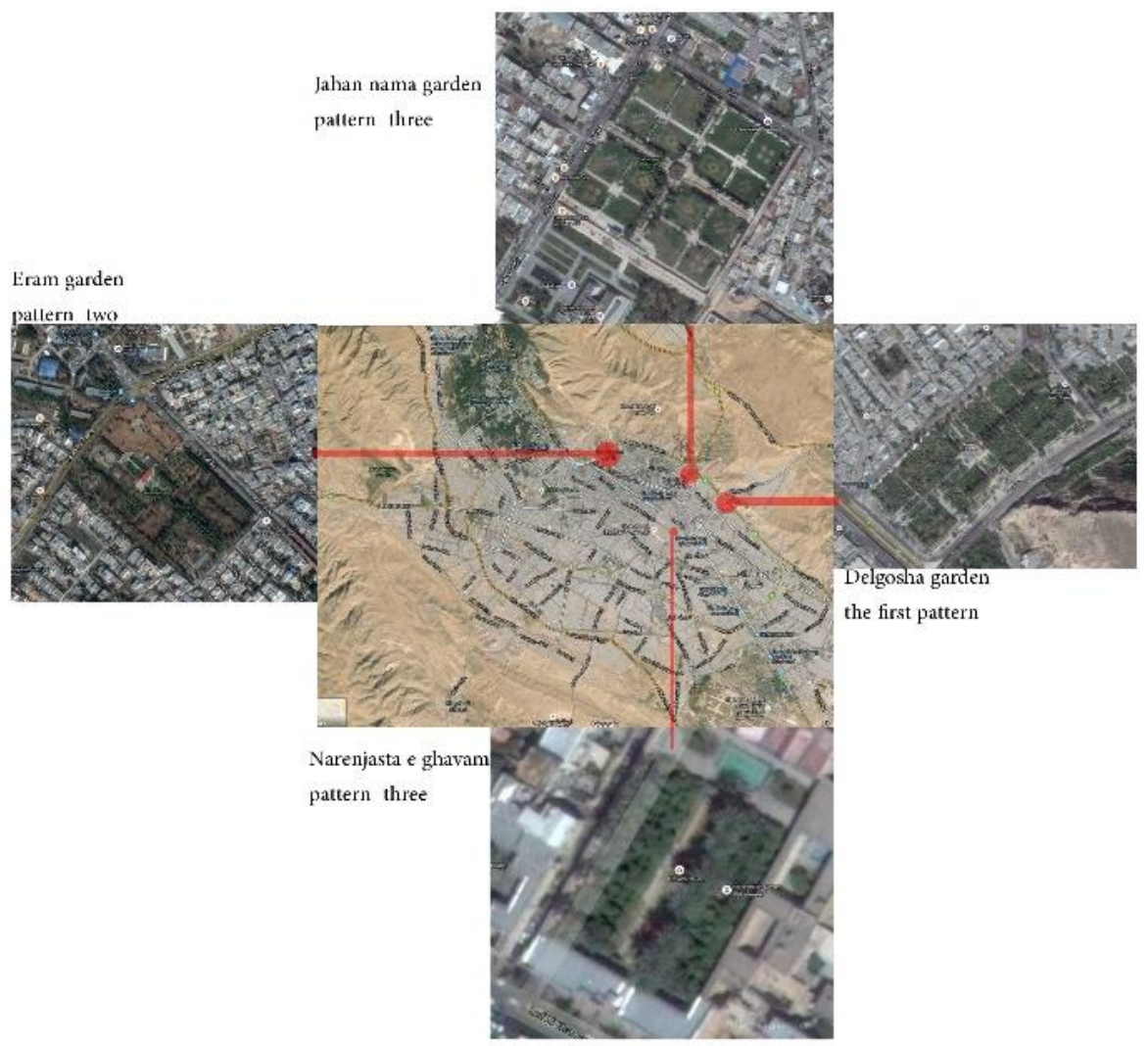

\section{Models of simulation}

The five above-mentioned forms of Persian garden were derived from Pirniya (1994), Soltan Zadeh (1999) and Ranjbar Kermani (2005). Persian garden is typically rectangular. After measuring the proportion of the rectangular of selected gardens, the 1.6 of proportion was selected and the size of a typical rectangular is $150 * 240$ meters and about the square pattern, the $150 * 150$ meters is considered. Ancient pattern of Pasargadae has been simulated based on its real dimension. Also, the dimension of the pavilion of the Pasargadae (KOSHK) is $75 * 35 * 10$ meters based on its real size.

According to the Fig. 9 \& Fig. 8 different conditions of modeling have been simulated: The materials of the wall are considered to be brick ( $U$ value of $0.31 \mathrm{w} / \mathrm{m}^{2} \mathrm{~K}$ ) and the pavements are concrete and the roofs have the albedo of asphalt. 


\section{Fig. 9: Simulation conditions}

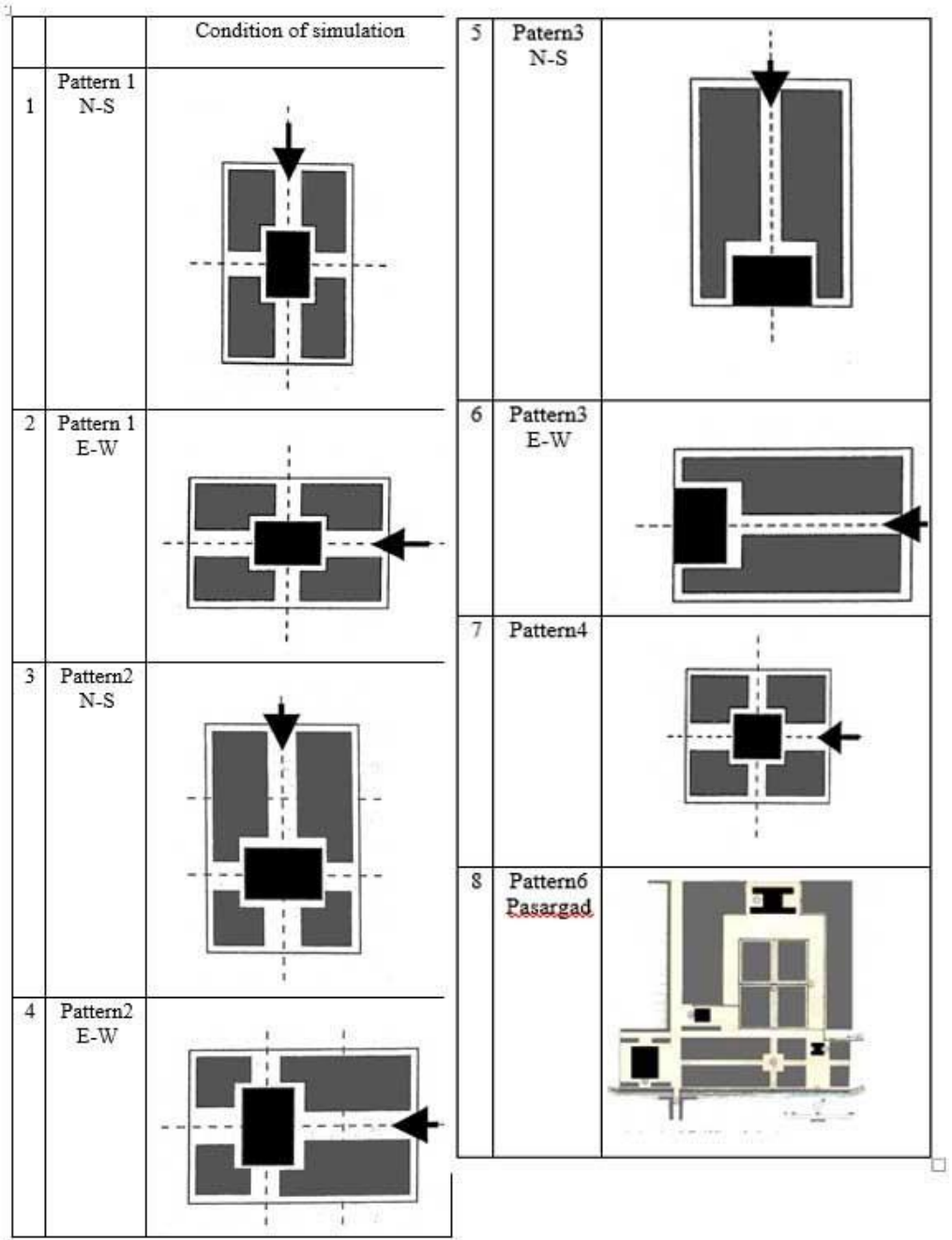

Simulation software

For the present study, $12^{\text {th }}$ of July 1998 as the hottest day of Shiraz was selected to check the potential of different patterns of Persian gardening (as one of the most referenced concepts of the landscape designing )in providing acceptable outdoor thermal comfort in summer hot days. In this regard, the simulations were done using the Envi-met3.1 software.

\section{Envimet 3.1.}

The ENVI-met3.1 is selected to simulate the atmospheric parameters (Envi-met.com, 2014). This software is the $3 \mathrm{D}$ microclimate based model that can evaluate the several aspects of the urban canyon, vegetation, materials albedo and etc., on outdoor thermal comfort and urban heat island mitigation (Bruse \& Fleer, 1998). ENVI-met is freeware software that has recently been used by researchers to simulate the effect of the urban vegetation on microclimate (Ali-Toudert, 2007; Chen \& Wong, 2006; Peng et al., 2013; 
Skelhorn et al., 2016). The software runs on a standard x86 personal computer running Windows XP or Vista and does -at the moment - not take advantage of more than one processor or distributed computing. Therefore the maximum number of grid cells is quite limited and it is not possible to simulate the micro-climate of whole cities but only single quarters within. ENVI-met uses a uniform mesh with a maximum of about $300 * 300 * 35$ cells with the horizontal extension ranging between $0.5-10 \mathrm{~m}$ and a typical vertical height of 1-5 $\mathrm{m}$ (Huttner et al., 2008). ENVI-met carries out the detailed calculation in regards to shortwave and long-wave radiation fluxes with respect to shading, reflection, and radiation from building systems and the vegetation, and it considers the evapotranspiration and sensible heat flux from the vegetation into the air, including full simulation of all physical plant parameters. ENVI-met has a typical spatial resolution from $0.5 \mathrm{~m}$ to $10 \mathrm{~m}$, and a temporal resolution of 10 seconds. A simulation should typically be carried out for at least 6 hours, but a 24-hour period is more usual. The optimal time to start a simulation is at night or sunrise so that the simulation can follow the solar radiation daily increase. ENVI-met requires an area input file with the 3- dimensional geometry, and a configuration file with the initialization input parameters (Akbari et al., 2015). The input parameter for vegetation in the ENVI-met model is that of leaf area density (LAD) $\left(\mathrm{m}^{2} \mathrm{~m}^{-3}\right)$ and consists of $10 \mathrm{LAD}^{3}$ values for each plant. The LAD values are in turn retrieved from a $\mathrm{LAI}^{4}$. The physiological properties of the plants in ENVI-met characterize parameters such as moisture absorption by roots, stomatal resistance, and albedo of leaves (Bruse, 2009).

\section{Rayman Model 1.2.}

This freeware is also specific outdoor-based-model (Thorsson et al., 2007). Rayman model generates several thermal indices like $\mathrm{PET}^{1}, \mathrm{SET}^{5}, \mathrm{PMV}^{6}$ and also accurate $\mathrm{Tmrt}^{7}$ of an urban setting. Rayman Meteorological input parameters to calculate the thermal indices are:

1. Air temperature

2. Vapor pressure

3. Wind speed

4. Mean radiant temperature

And body parameters used in MEMI are

1: Human activity and body heat production

2: Heat transfer resistance of clothing. ( Matzarakis et al., 2007).

So in this study, these two models were used to calculate the atmospheric data and also the PET $^{1}$. Therefore in the initial stage, the climatic data were derived from ENVI-met model and the results were imported to Rayman 2.1 model to calculate the $\mathrm{PET}^{1}$ for a normal pedestrian. 
Ojaghlou M., Khakzand M.: Thermal comfort characteristic of 5 patterns of a Persian garden in a hot-arid climate of Shiraz. Iran

\section{Table 1: Conditions used in the simulations with ENVI-met 3.1}

\begin{tabular}{|c|c|}
\hline Simulation day & 12.07 .1998 \\
\hline Simulation period & $14 \mathrm{~h}(6: 00-20: 00)$ \\
\hline Spatial resolution & $1 \mathrm{~m}$ horizontally,2m vertically \\
\hline Initial Temperature & $300.15(27){ }^{\circ} \mathrm{C}$ \\
\hline Wind speed & $3 \mathrm{~m} / \mathrm{s}$ \\
\hline Wind direction (N=0,E=90) & 315 \\
\hline Relative humidity (in $2 \mathrm{~m})$ & $293 \mathrm{~K}\left(20^{\circ} \mathrm{C}\right)$ \\
\hline Indoor temperature & Wall=1.6 w/m ${ }^{2}$ \\
\hline Heat transmission & Wall $=0.21 \mathrm{roofs}=0.18$ \\
\hline albedo & 0.0 \\
\hline Walking Speed (m/s) & 116 \\
\hline Energy-Exchange (Col. 2 M/A) & 0.0 \\
\hline Mech. Factor & 0.5 \\
\hline Heat transfer resistance cloths & 300 \\
\hline Initial Temperature Upper Layer $(0-20 \mathrm{~cm})$ & 298.15 \\
\hline Initial Temperature Middle Layer $(20-50 \mathrm{~cm})$ & 229.4 \\
\hline Relative Humidity Upper Layer $(0-20 \mathrm{~cm})$ & 32 \\
\hline Relative Humidity Middle Layer $(20-50 \mathrm{~cm})$ & 34 \\
\hline Relative Humidity Deep Layer $($ below $50 \mathrm{~cm})$ & 37 \\
\hline
\end{tabular}

Table 2: Long time meteorological data of Shiraz (1971-2011) (farsmet.ir, 2016)

\begin{tabular}{|l|l|l|l|l|l|l|l|l|l|}
\hline & $\begin{array}{l}\mathrm{T}_{\mathrm{a}} \\
(\min )\end{array}$ & $\begin{array}{l}\mathrm{T}_{\mathrm{a}} \\
(\max )\end{array}$ & $\begin{array}{l}\mathrm{T}_{\mathrm{a}} \\
(\text { mean })\end{array}$ & $\begin{array}{l}\text { RH\% } \\
(\min )\end{array}$ & $\begin{array}{l}\text { RH\% } \\
(\max )\end{array}$ & $\begin{array}{l}\text { RH\% } \\
(\text { mean })\end{array}$ & $\begin{array}{l}\text { Wind m/s } \\
\text { speed }\end{array}$ & $\begin{array}{l}\text { Wind } \\
\text { dir }\end{array}$ & PET \\
\hline March & 8.1 & 22.3 & 15.2 & 24 & 72 & 48 & 15 & 251 & 10.6 \\
\hline April & 12.9 & 28.9 & 20.9 & 16 & 57 & 37 & 15 & 256 & 17.2 \\
\hline May & 17.2 & 35.2 & 26.2 & 10 & 39 & 25 & 13 & 271 & 23.8 \\
\hline June & 20.6 & 38.2 & 29.4 & 10 & 38 & 24 & 12 & 224 & 30.5 \\
\hline July & 20.6 & 37.7 & 29.2 & 11 & 41 & 26 & 12 & 249 & 30.1 \\
\hline August & 16.9 & 35.2 & 26.1 & 11 & 44 & 28 & 12 & 248 & 24.5 \\
\hline September & 11.7 & 29.8 & 20.8 & 12 & 52 & 32 & 12 & 275 & 17.5 \\
\hline October & 6.4 & 22.7 & 14.6 & 21 & 67 & 44 & 11 & 259 & 10.2 \\
\hline November & 2.2 & 16.2 & 9.2 & 31 & 78 & 54 & 12 & 238 & 3.4 \\
\hline December & 0.6 & 12.7 & 6.6 & 37 & 85 & 61 & 12 & 234 & 0.3 \\
\hline January & 1.1 & 13.5 & 7.3 & 32 & 81 & 57 & 13 & 237 & 1.1 \\
\hline February & 4.4 & 17.8 & 11.1 & 26 & 76 & 51 & 15 & 234 & 5 \\
\hline
\end{tabular}

Three-dimensional tree canopy structure

In the Envi-met model, plants are considered as a one-dimensional permeable column which is subdivided into multiple $\mathrm{LAD}^{3}$ layers, expressed as $\mathrm{m}^{2} \mathrm{~m}^{-3}$ (Wania et al., 2012). To account for the effect of greenery on atmospheric procedures, all predictive equations in the model are extended into the vegetation layers using source/sink terms describing heat, humidity and momentum exchanges (Wania et al., 2012; Hofman et al., 2016).

Within ENVI-met, vertical $\mathrm{LAD}^{3}$ profiles are normalized from $\mathrm{z} \mathrm{h}^{-1}=0.1$ (LAD1) to $\mathrm{z} \mathrm{h}^{-1}=1$ (LAD10), where $\mathrm{z}$ is the height of the LAD ${ }^{3}$ entry and $\mathrm{h}$ is the total plant height $(\mathrm{m})$. Each vertical profile thus consisted of 10 different horizontal $\mathrm{LAD}^{3}$ layers. For the theoretical tree crown representation, we used 8 unique vertical $\mathrm{LAD}^{3}$ profiles to be able to adjust the 
tree crown dimensions in relation to the distance to the center of the crown. The applied $\mathrm{LAD}^{3}$ values $\left(0.1-1.15 \mathrm{~m}^{2} \mathrm{~m}^{-3}\right)$ were based on standard deciduous $\mathrm{LAD}^{3}$ values provided in the local ENVI-met database consisting of 27 different plant structures (Bruse, 2012). Therefore in this particular study, 3 meters dense trees with the ID $=\mathrm{dm}$ (Tree $3 \mathrm{~m}$ dense, distinct crown layer) with grass below was used in order to achieve more accurate results based on the actual trees which are used in the traditional gardens in the Shiraz.

Fig. 10: Example of common trees in the traditional Gardens of Shiraz

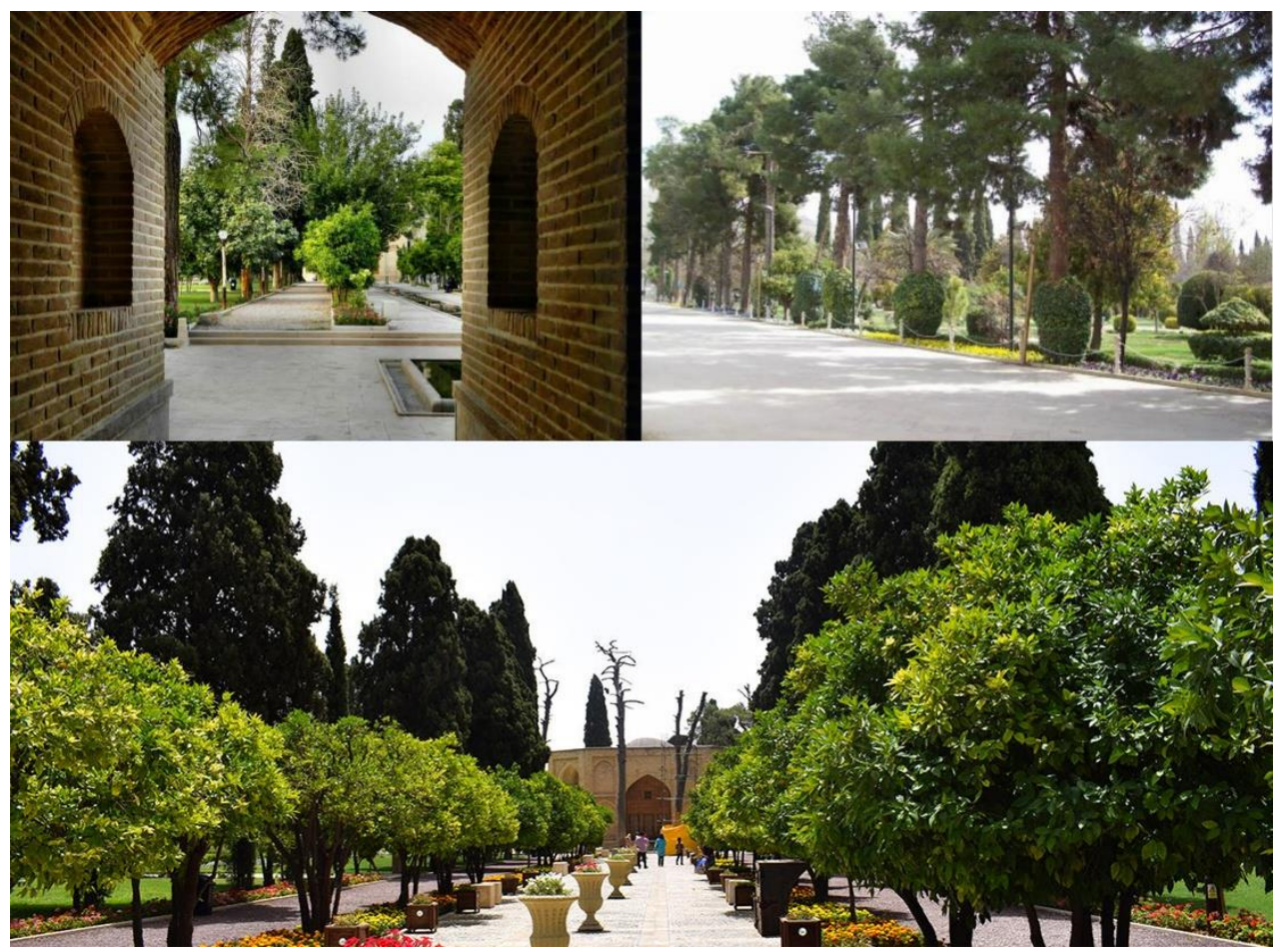

Table 3: List of the plants used in the simulation

\begin{tabular}{|c|c|}
\hline Plant's ID & Description \\
\hline Dm & Tree $20 \mathrm{~m}$ dense, distinct crown layer(Deciduous tree) \\
\hline $\mathrm{g}$ & Grass $50 \mathrm{~cm}$ aver. dense \\
\hline
\end{tabular}

Weather data

The climate of Shiraz $\left(29^{\circ} \mathrm{N}, 52^{\circ} \mathrm{E}\right)$, is known as hot - arid climate (Pourvahidi \& Ozdeniz, 2013). The prevailing wind direction is South-West. The mean annual dry bulb temperature is $17.3^{\circ} \mathrm{C}$. The maximum air temperature for the reference day $(12.07 .1998)$ is recorded $42^{\circ} \mathrm{C}$. 
The climatic data of Shiraz is represented monthly from 1986 to 2005 . The calculations of $\mathrm{PET}^{1}$ are done via Rayman for a normal 35-year old male person of $1.75 \mathrm{~m}$ high and $75 \mathrm{~kg}$, with a metabolic rate of $80 \mathrm{Watt}$. An activity level of $80 \mathrm{~W}$ when a normal person is walking with $1.2 \mathrm{~m} / \mathrm{s}$ (Fig.11).

Fig. 11: PET frequency (1971-2011)

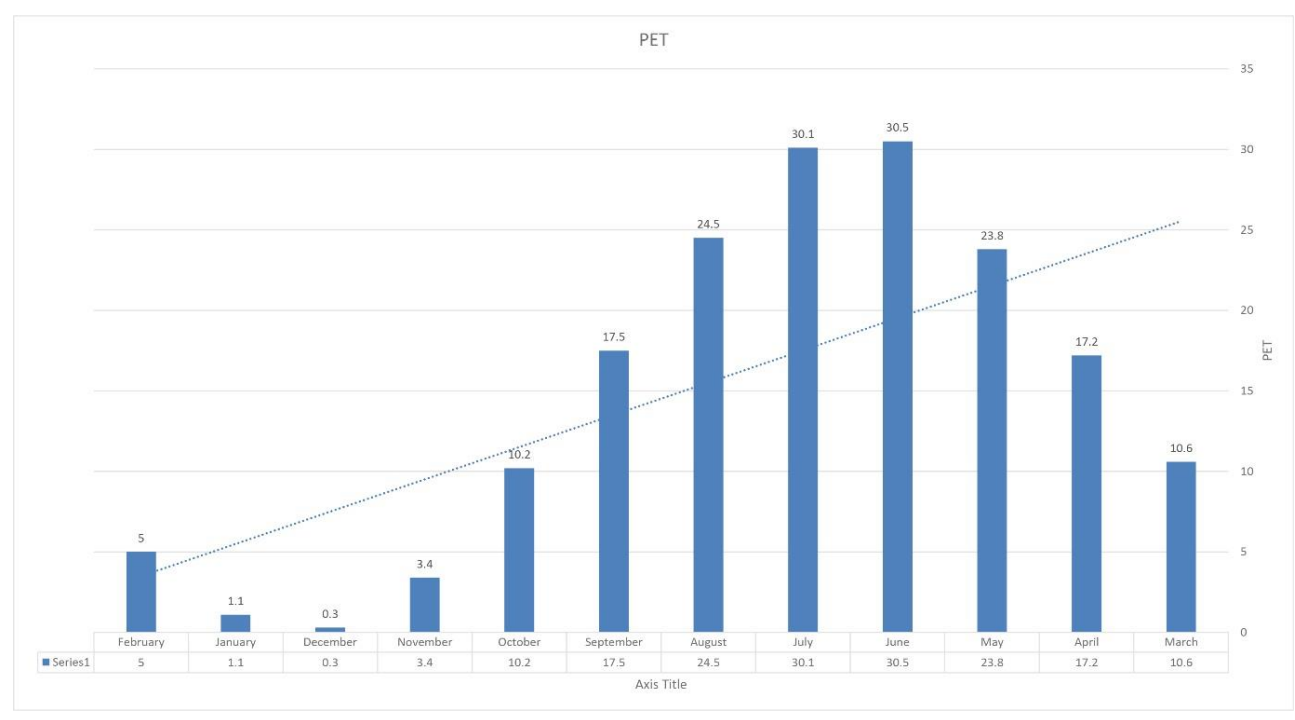

\section{Validation of ENVI-met}

Reliability of Envi-met for calculating and simulating the thermal performance of outdoor condition has been proven constantly (Taleghani et al, 2014; Yahia \& Johansson, 2014; Qaid \& Ossen, 2014; Johansson, 2006; Srivanit \& Hokao, 2013).

These studies demonstrated an agreement between measured (from field measurements or observed data at local meteorological stations) and simulated air temperatures.

In order to calibrate the model used in this paper, the measured hourly average meteorological data (such as air temperature, relative humidity, wind speed, $\mathrm{Tmrt}^{7}$ ) have been compared with simulated outputs of Envi-met model for the built environments of the Eram garden of Shiraz. In order to reduce the radiation effect on the measured $\mathrm{Ta}^{8}$, the air temperature sensor was protected by the white buffer. The gardens environment was measured for 10 days in July of 2014. Two random days, July $13^{\text {th }}$ and $18^{\text {th }}$ were selected for Envi-met simulation. All the data was measured at $1.6 \mathrm{~m}$ height. The data from simulations and measurements are compared in Fig. 11 \& Fig. 12 to show the accuracy of the simulation results. An Envi-met Area file and a configuration file are needed for the simulation. The simulation input data is the same as Area input file (Table.4). 
Table 5: The conditions used in the validation simulations

\begin{tabular}{|c|c|c|}
\hline Simulation day & 13.07 .2014 & 18.07 .2014 \\
\hline Simulation period & $24 \mathrm{~h}(21: 00-21: 00)$ & $24 \mathrm{~h}(21: 00-21: 00)$ \\
\hline Spatial resolution & $\begin{array}{l}1 \mathrm{~m} \text { horizontally, } 2 \mathrm{~m} \\
\text { vertically }\end{array}$ & $\begin{array}{l}1 \mathrm{~m} \text { horizontally, } 2 \mathrm{~m} \\
\text { vertically }\end{array}$ \\
\hline Wind speed & $6 \mathrm{~m} / \mathrm{s}$ & $0 \mathrm{~m} / \mathrm{s}$ \\
\hline Wind direction $(\mathrm{N}=0, \mathrm{E}=90)$ & 90 & - \\
\hline Relative humidity (in $2 \mathrm{~m}$ ) & $52 \%$ & $46 \%$ \\
\hline Indoor temperature & $293 \mathrm{~K}\left(20^{\circ} \mathrm{C}\right)$ & $293 \mathrm{~K}\left(20^{\circ} \mathrm{C}\right)$ \\
\hline Heat transmission & Wall $=1.6 \mathrm{w} / \mathrm{m}^{2}$ & Wall $=1.6 \mathrm{w} / \mathrm{m}^{2}$ \\
\hline albedo & Wall $=0.21$ roofs $=0.18$ & Wall $=0.21$ roofs $=0.18$ \\
\hline Walking Speed $(\mathrm{m} / \mathrm{s})$ & 0.0 & 0.0 \\
\hline Energy-Exchange (Col. $2 \mathrm{M} / \mathrm{A})$ & 116 & 116 \\
\hline Mech. Factor & 0.0 & 0.0 \\
\hline Heattransfer resistance cloths & 0.5 & 0.5 \\
\hline Initial Temperature Upper Layer $(0-20 \mathrm{~cm})$ & 298.15 & 296.15 \\
\hline Initial Temperature Middle Layer $(20-50 \mathrm{~cm})$ & 296.35 & 293.15 \\
\hline $\begin{array}{c}\text { Initial Temperature Deep Layer (below } 50 \\
\mathrm{~cm})\end{array}$ & 292.42 & 289.3 \\
\hline Relative Humidity Upper Layer $(0-20 \mathrm{~cm})$ & 52 & 46 \\
\hline $\begin{array}{c}\text { Relative Humidity Middle Layer } \\
(20-50 \mathrm{~cm})\end{array}$ & 55 & 48 \\
\hline $\begin{array}{l}\text { Relative Humidity Deep Layer } \\
\text { (below } 50 \mathrm{~cm} \text { ) }\end{array}$ & 59 & 52 \\
\hline
\end{tabular}

For the configuration file, an area of $188 * 307$ is modeled. The measured and simulated dry bulb temperature during the $13^{\text {th }}$ and $18^{\text {th }}$ of July is compared in Figs. 12, 13. In the first day, the frequency of $\mathrm{Ta}^{8}$ between the measurement and the simulated data is more or less the same, and according to the Fig. 12, the peak Ta of measurement is $0.7^{\circ} \mathrm{C}$ higher than the simulation. In the second day, 18th of July, based on Fig. 13, the peak Ta of the hottest hour is not that much different from the first day and it was about $0.5^{\circ} \mathrm{C}$ higher than the simulated data. The root means square deviation is a frequently used measure of the difference between values predicted by estimator and values actually observed experimentally. The difference in the observed and simulated data could be the fact that Envi-met does not include sky situation and cloudiness in its input parameters. 
Ojaghlou M., Khakzand M.: Thermal comfort characteristic of 5 patterns of a Persian garden in a hot-arid climate of Shiraz. Iran

\section{Fig. 12: Simulated and measured data of $13^{\text {th }}$ July of 2014}

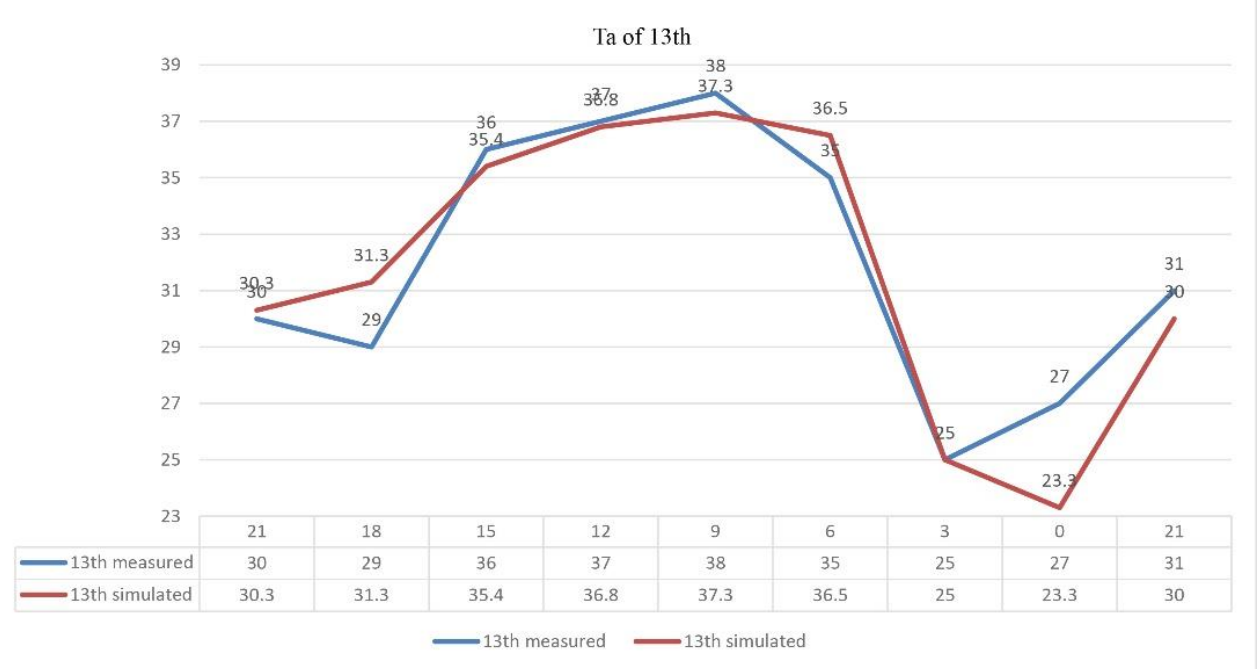

Fig. 13: Simulated and measured data of $18^{\text {th }}$ July of 2014

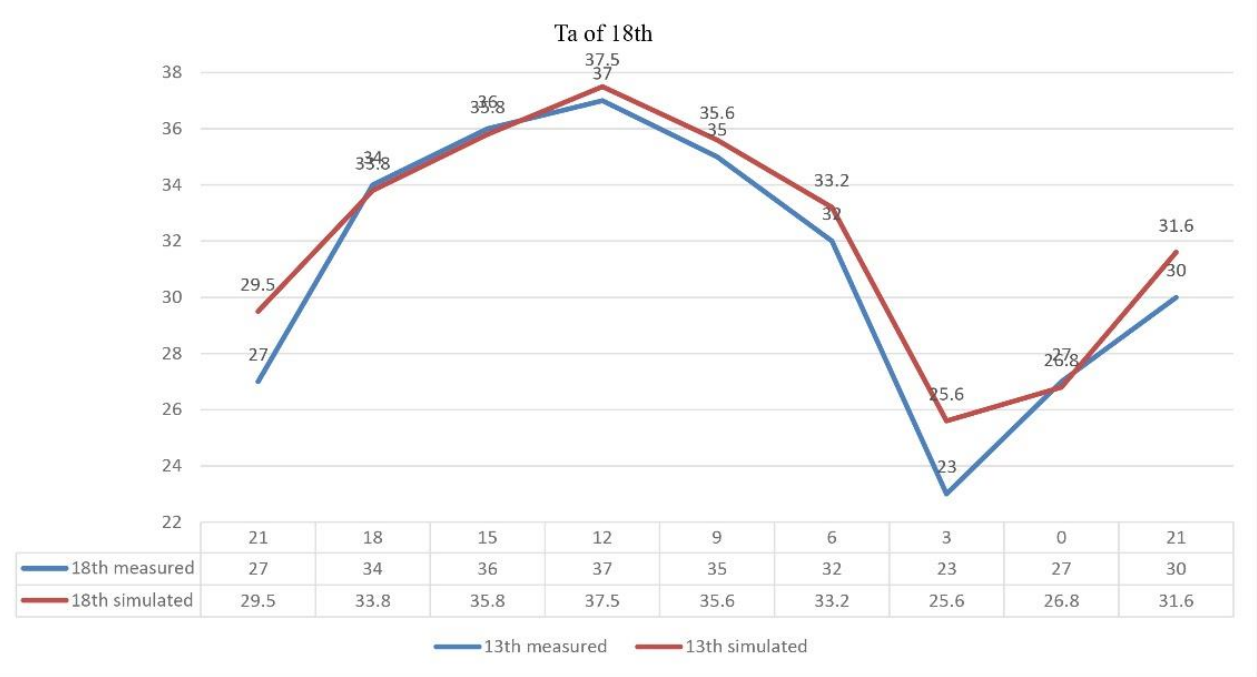




\section{LITERATURE REVIEW}

\section{Literature review}

\section{Thermal indices}

Human thermal perceptions are measured and simulated by thermal indices; therefore these indices show the climate effect on the human body (Nastos \& Matzarakis, 2012; d'Ambrosio Alfano, 2011).

The equation of energy balance which calculates the thermal Physiology and energy balance of the human body is a very fundamental issue in thermal comfort indices. The equation of the energy balance is expressed by the following equation (Höppe, 1999).

$$
\mathrm{M}+\mathrm{W}+\mathrm{R}+\mathrm{C}+\mathrm{ED}+\mathrm{ERe}+\mathrm{ESw}+\mathrm{S}=0
$$

$\mathrm{M}^{9}$ is the metabolic rate, $\mathrm{W}^{10}$ is the physical work output, $\mathrm{R}^{11}$ is the net radiation of the body, $\mathrm{C}$ is outdoor. condition like $\mathrm{UTCI}^{\mathrm{I} 2}$ (Błazejczyk et al., 2010), ETVO index (Nagano \& Horikoshi, 2011), ETF ${ }^{13}$ (Kurazumi et al., 2011), SET $^{5}$ (Kinouchi,2001), improved SET* (Pickup \& DE Dear, 1999) PMV6 (Jendritzky \& Nübler, 1981; Matzarakis \& Mayer, 1997; Vu et al., 19981; Thorsson et al., 2004; Hodder \& Parsons, 2007) PET $^{1}$ (VDI, 1998; Matzarakis et al., 1999; Svensson et al, 2003; Gulyás et al., 2006; Matzarakis et al., 2007; Bouyer et al., 2007; Alexandri \& Jones, 2008; Hwang et al., 2011). Among these indices which have been used by researchers, Matzarakis and Amelung showed that the PET $^{1}$ is the most accurate thermal index for assessing the climate effect on human being comfort condition (Matzarakis \& Amelung, 2008). In the calculation of PET $^{1}$, the most important variables of human thermal comfort such as airflow, air temperature, mean radiant temperature, humidity and etc., are engaged. Also, it is important to notice that the outcome of PET $^{1}$ is still Celsius and therefore it is not comprehensible for experts in meteorology. Comfort classification of PET $^{1}$ scale is described in the table below.

Table 6: PET thermal comfort category (Hoppe, 1999)

\begin{tabular}{|c|c|c|}
\hline PET ${ }^{\circ} \mathrm{C}$ & Thermal Perception & Grade of physiological stress \\
\hline Below+4 & Very cold & Extreme cold stress \\
\hline 4 to 8 & Cold & Strong cold stress \\
\hline 8 to 13 & Cool & Moderate cold stress \\
\hline 13 to 18 & Slightly cool & Slight cold stress \\
\hline 18 to 23 & Comfortable & No thermal stress \\
\hline 23 to 29 & Slightly warm & Slight heat stress \\
\hline 29 to 35 & Warm & Moderate heat stress \\
\hline 34 to 41 & Hot & Strong heat stress \\
\hline $41<$ & Very hot & Extreme heat stress \\
\hline
\end{tabular}

\section{Urban park studies}

Based on the relevant literature, the application of greenery in urban areas would modify the microclimate factors such air temperature, relative humidity, and wind speed (Byrne et al., 2008; Lee et al., 2009; Jim, 2012). Therefore, due to mitigation of heat stress and urban heat island, (UHI) green cities are recommended to enhance thermal adaptation behavior 
Ojaghlou M., Khakzand M.: Thermal comfort characteristic of 5 patterns of a Persian garden in a hot-arid climate of Shiraz. Iran

(Givoni, 1991; Gill et al., 2007; Ahn et al., 2014). In this regard, the effect of greening in urban areas has been investigated in a different field. Urban parks play an essential role in mitigating the heat island effect and improve pedestrian thermal comfort (Yabe \& Nakamura, 2010; Oliveira et al., 2011; Cohen et al., 2013; Müller et al., 2014; Brown et al., 2015). The first efforts on studying the cooling effect of PCI have been reported by Spronken and Oke in 1998. They proved that urban parks are $1-3{ }^{\circ} \mathrm{C}$ cooler than their surrounding urban areas. In 2007 Chang et al carried out a preliminary study on 61 city parks in Taipei, they showed that the park's surrounded area was $0.81 \mathrm{~K}$ cooler than city areas. Studying on outdoor thermal comfort especially the research on urban parks has rarely been carried out in Iran. In 2010 Monam \& Behzadfar investigated the $\mathrm{SVF}^{2}$ effect on outdoor comfort in urban areas (Tehran selected parks). They studied 78 points of the selected parks and showed that correlation of Sky view factor and Mean radiant temperature and Spherical temperature are more than other environmental parameters. Regarding Persian gardens, most of the studies were focused on quality of sense of place (Katouzian, 1986; Zarabadi et al., 2011; Medghalchi et al., 2014), cultural (Bateson, 1993) and other aspects of Persian garden (except microclimatic aspect). In most of the studies, it was mentioned that microclimatic effect of Persian garden is the most important feature of these gardens, whereas climatic studies on these gardens can rarely be found. In these fields, only the shading role of Persian garden can be mentioned. Taghvaei et al. (2015) have studied the winter and summer comfort conditions in two gardens of Shiraz. This experimental study shows that on the hottest day of summer, the gardens are cooler than the city (up to 11 degrees) and in winter they are also cooler than the city.

\section{RESULTS AND DISCUSSION}

\section{Results of simulation}

As explained before, the Persian garden is one of the most important landscapes design concepts, at least in the Middle East and also especially in Iran. The most important Persian gardens are located in Shiraz as one of the garden-based cities in Iran. Lack of sufficient thermal investigation of Persian gardens in Iran has made us evaluate the thermal characteristic of the Persian garden in Shiraz context. For this purpose 5 patterns of Persian garden with its related garden in Shiraz has been simulated in 8 conditions on the hottest day of the year in 1998. The reference points for collecting the environment data has been located at the start, middle, and end of each path of the Persian garden paths. Fig.14 shows the air temperature and wind speed at the hottest time of the reference year for these models. 
Fig. 14: $\mathrm{Ta}^{8}$ (left) and wind speed (right), Leonardo visualization of the patterns in $12^{\text {th }}$ of July of 1998

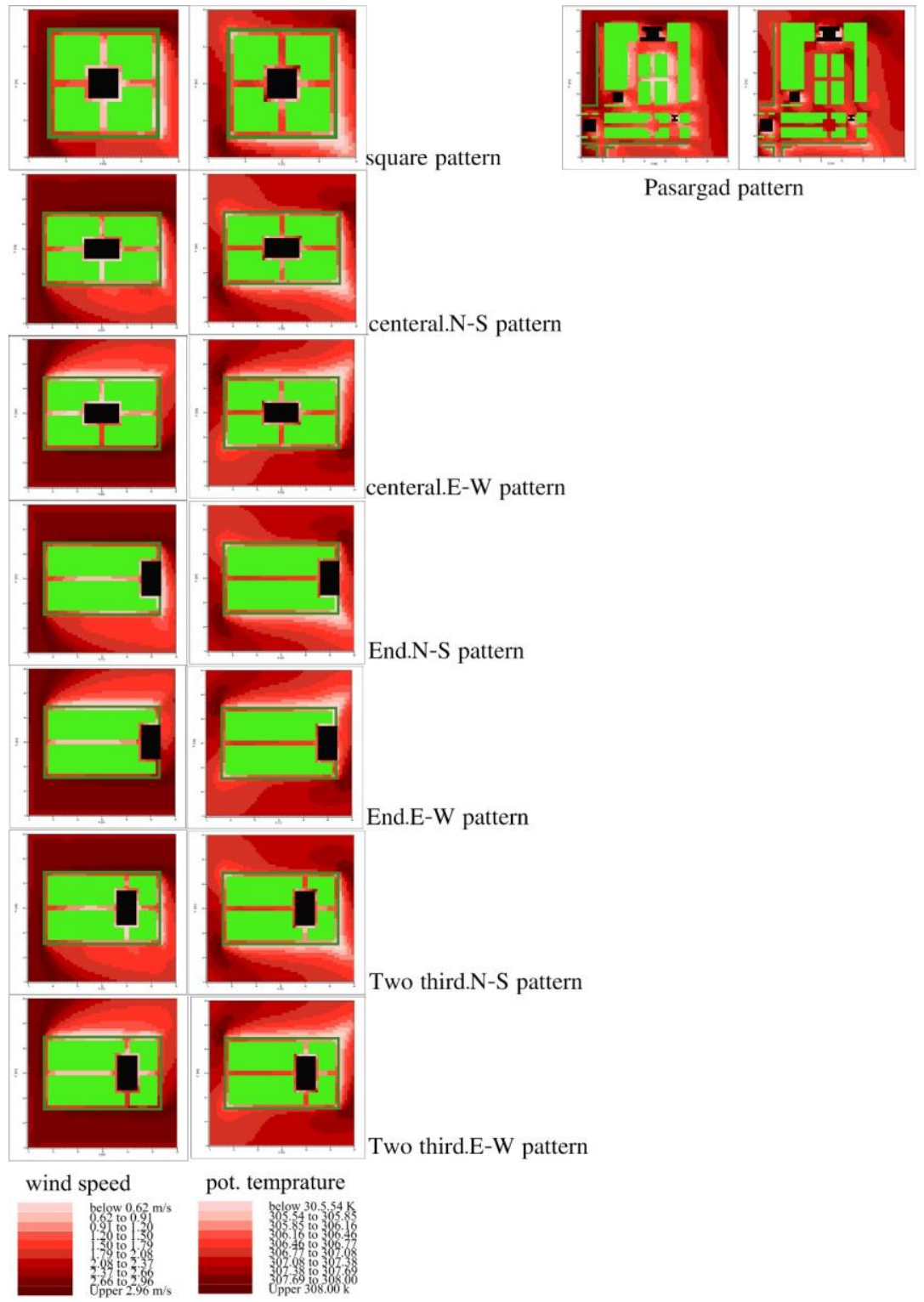

At the first look to the air temperature, the average of receptors data of $\mathrm{Ta}^{8}$ is $28^{\circ} \mathrm{C}$ inside the gardens with a little different with each other, so accordingly the Square pattern with $28.18^{\circ} \mathrm{C}$ has the lowest temperature and $2 / 3$ pattern with $\mathrm{E}-\mathrm{W}$ orientation with $28.64^{\circ} \mathrm{C}$ has the highest temperature. Frequency average of $\mathrm{Tmrt}^{7}$ of the patterns can be described by the following chart. Based on the chart between rectangular patterns, the End N-S pattern has the highest temperature. The End E-w has the lowest Tmrt ${ }^{7}$. Out of these two patterns, Tmrt of the other rectangular patterns, is about in $55-56^{\circ} \mathrm{C}$ range. So between all patterns, the 
Ojaghlou M., Khakzand M.: Thermal comfort characteristic of 5 patterns of a Persian garden in a hot-arid climate of Shiraz. Iran

Pasargadae has the worst condition and the End E-W has the best condition in terms of the mean radiant temperature. According to Tmrt comparison (Diagram15), the End E-w has the lowest amount of $\mathrm{Tmrt}^{7}$ (with $0.767 \mathrm{SVF}^{2}$ ) and the Pasargadae pattern garden has the highest Tmrt. Based on the diagram 15 the maximum of mean radiant temperature is related to the period between 13:00 to 16:00 and peak of $\mathrm{Tmrt}^{7}$ are related to the 15:00 with $78.295^{\circ} \mathrm{C}$. Between 16:00 to19:00 the $\mathrm{Tmrt}^{7}$ values do not fluctuate a lot. This condition also happens from 11:00 to 13:00 but by 13:00 there are 2 points with sudden alterations of Tmrt ${ }^{7}$. These changes are related to the time after 13:00 and 19:00. In the first one, Tmrt ${ }^{7}$ values start to increase suddenly and in the second one, the $\mathrm{Tmrt}^{7}$ values start to decrease suddenly.

\section{Fig. 15: Frequency average of mean radiant temperature of the patterns}

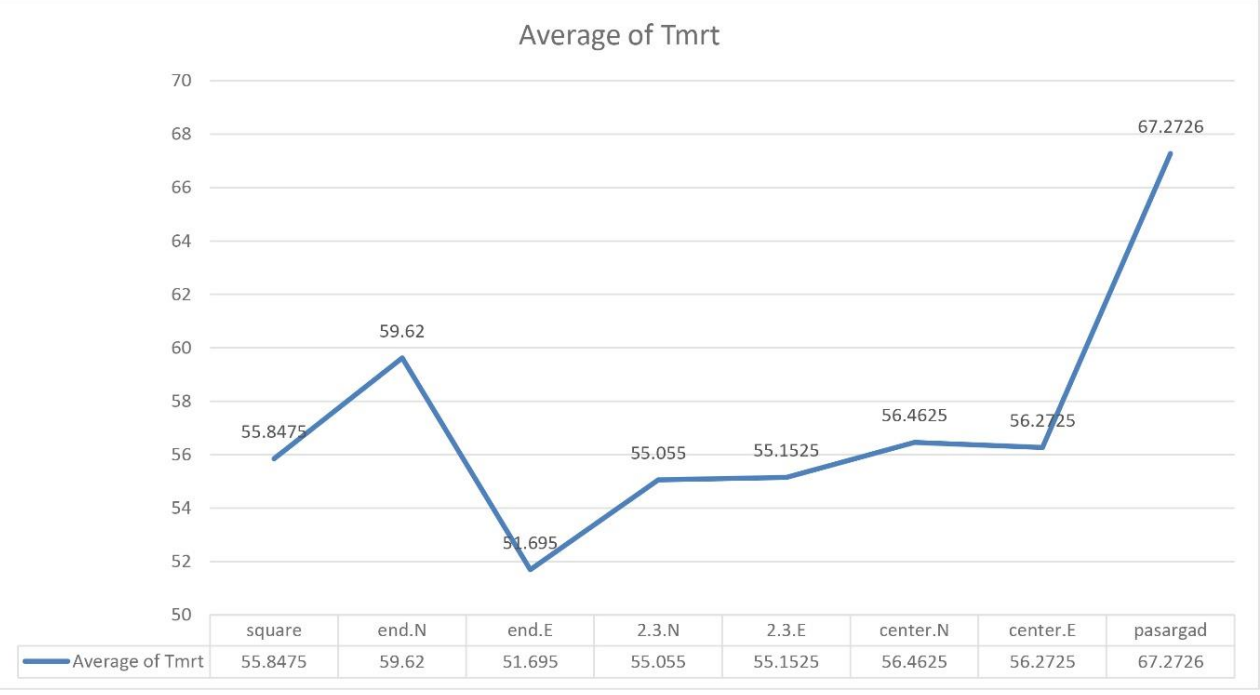

However, the maximum of the air temperature occurs in 17:00 but a maximum of the SW.dir ${ }^{14}$ occurs in 15:00, so the correlation of $\mathrm{Tmrt}^{7}$ and air temperature, SW.dir ${ }^{14}$ and SW.diff ${ }^{15}$ have been calculated by SPSS software. About Tmrt ${ }^{7}$ and the $\mathrm{Ta}^{8}$ changes and their correlation, the -0.12 of R-value has been derived from SPSS software. But solar radiation fluxes and its relation with mean radiation can be analyzed by SW.dir ${ }^{14}$ and SW.diff ${ }^{15}$ separately. The SW.dir ${ }^{14}$ frequency is more than $90 \%$ based on $\mathrm{Tmrt}^{7}$ frequency, it means that the maximum of SW.dir ${ }^{14}$ happens in 14:00 and the correlation of this value and mean radiant temperature is 0.93 of $\mathrm{R}$-value. This also true about diffuses radiations and it has a high correlation with $\mathrm{Tmrt}^{7}$ and it is 0.77 of R-value. All of these facts lead us to cross out the exposed paths of the gardens to the afternoon sun rays. In the E-W orientation of the garden, there are similarly oriented paths that are exactly exposed to the west afternoon sun radiation, but in the End E-W pattern, the pavilion is located in the far west of the garden which provides a good obstacle to the afternoon strong sun rays. Therefore, due to wry radiation of sun rays in the afternoon, long shadows are formed on the path and it can control the amount of radiation. Thus, this quality shall protect the pedestrians in the garden from direct exposure to sunlight. Hourly frequency of the SW.dir of end.E-W pattern is described in Fig.16. 


\section{Fig. 16: Hourly frequency of Tmrt of End.E-W pattern}

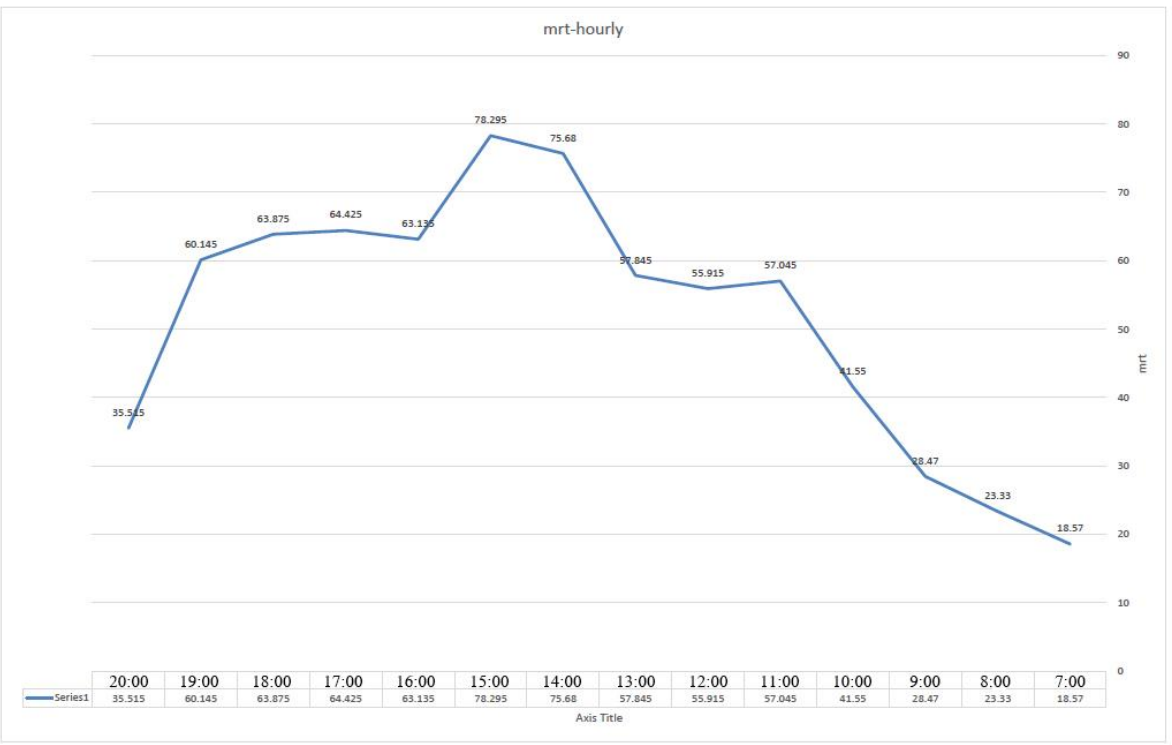

In contrast, there are some supporting facts in the Pasargadae pattern that cause the environment to have more mean radiant temperature compared to other patterns. The average $\mathrm{SVF}^{2}$ of 9 receptors is calculated and 0.933 of $\mathrm{SVF}^{2}$ shows high sky exposure and more opportunity arises for pedestrians to reach more solar radiation. As mentioned above, between 8 conditions of simulations, the Pasargadae pattern reaches the highest amount of $\mathrm{Tmrt}^{7}$ than the others. Average of the hourly frequency of Tmrt ${ }^{7}$ is described in Fig. 17.

\section{Fig. 17: SW.Dir frequency of the End.E-W pattern}

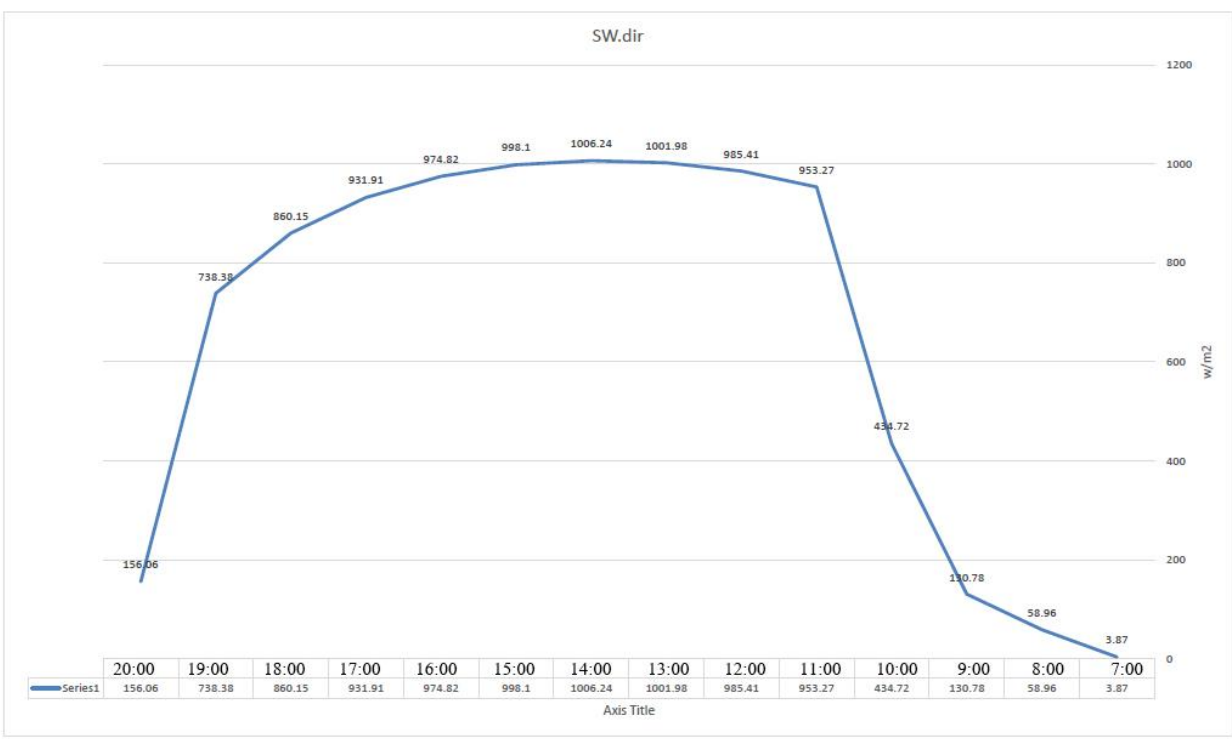


According to the diagram 20, the time between 9:00 to 19:00 include high amounts of this diagram and in comparison with the other patterns, the Pasargadae pattern is engaged with mean radiant temperature 3 hours more than the coolest one. According to the diagram, the Peak of Tmrt ${ }^{7}$ occurs at 18:00 and it is $76.265^{\circ} \mathrm{C}$. The Tmrt ${ }^{7}$ drops considerably just by the sunset which means after the 19:00 it decreases to its minimum level in the afternoon and it lasts just for an hour. The diagram shows a similar behavioral pattern at dawn. By sunrise, the diagram of $\mathrm{Tmrt}^{7}$ starts to rise more rapidly than the others. The maximum air temperature occurs at 17:00, (contrary to the End.E-W) thus, $\mathrm{Tmrt}^{7}$ has a strong correlation of $0.82 \mathrm{R}$ with the Ta. As mentioned above, high $\mathrm{SVF}^{2}$ value of Pasargadae (0.933) creates more sky exposure to this garden, so this condition creates more opportunities to the surfaces and pedestrians to receive more solar radiation, both directly and diffusely. Alongside this fact, different orientation of the paths and the trees provides the paths with more opportunities to reach afternoon strong sun rays. Consequently, these two factors contribute to the high correlation between the mean radiant temperature and air temperature. In the Pasargadae pattern, the paths that are facing the west have more $\mathrm{Tmrt}^{7}$. Hence, the correlation between the Tmrt ${ }^{7}$, SW.dir ${ }^{14}$, and SW.diff ${ }^{15}$ will be high enough. R-value of the Tmrt ${ }^{7}$ and SW.dir ${ }^{14}$ is 0.94005 and correlation of SW.diff ${ }^{15}$ is 0.8653 of R. This means that in this kind of gardens, the maximum of the Tmrt ${ }^{7}, \mathrm{Ta}^{8}, \mathrm{SW} \cdot \operatorname{dir}^{14}$, and SW.diff ${ }^{15}$ occur at 17:00. The alteration of $\mathrm{Tmrt}^{7}$ depends on the $\mathrm{Ta}^{8}$ and sun radiation, so in this condition, it is extremely difficult to control the climatic and environmental parameters to modify the garden microclimate. In Fig. 19, The Tmrt ${ }^{7}$ of these two models has been described visually.

Fig. 18: Average of the hourly frequency of Tmrt of Pasargadae pattern

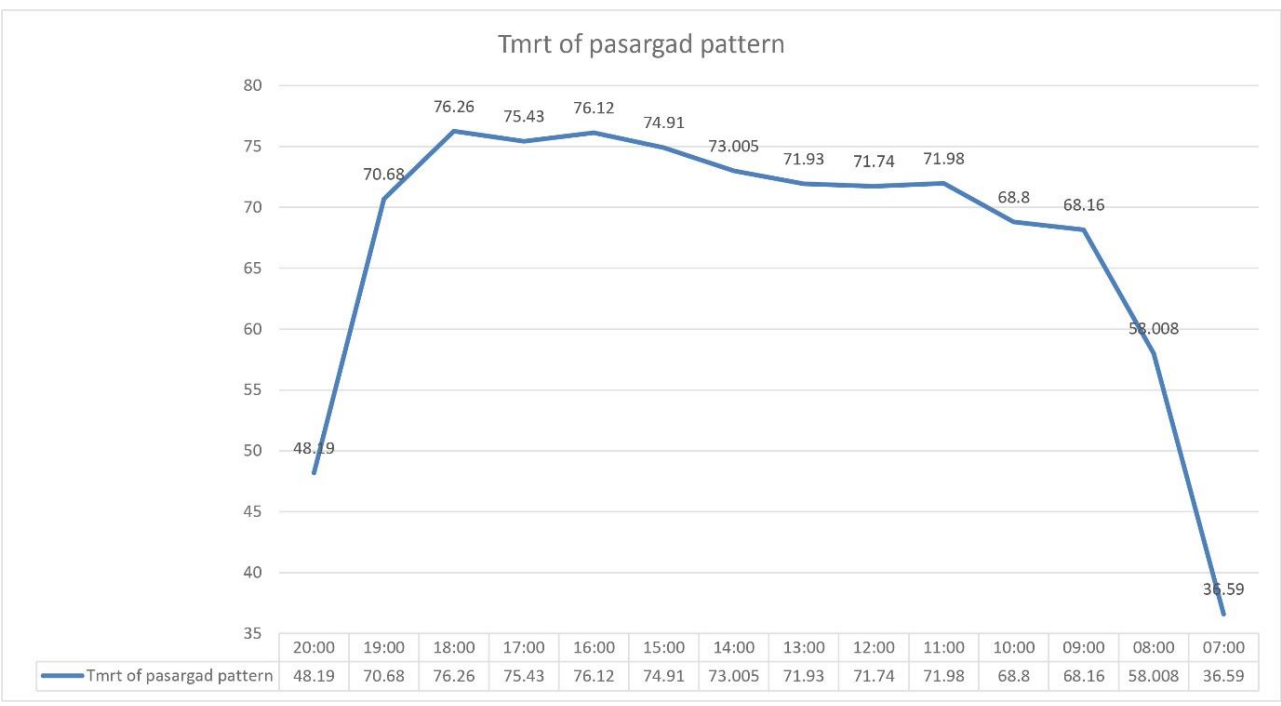


Fig. 19: Tmrt of the End.E-w \& Pasargadae patterns in the hottest time of day
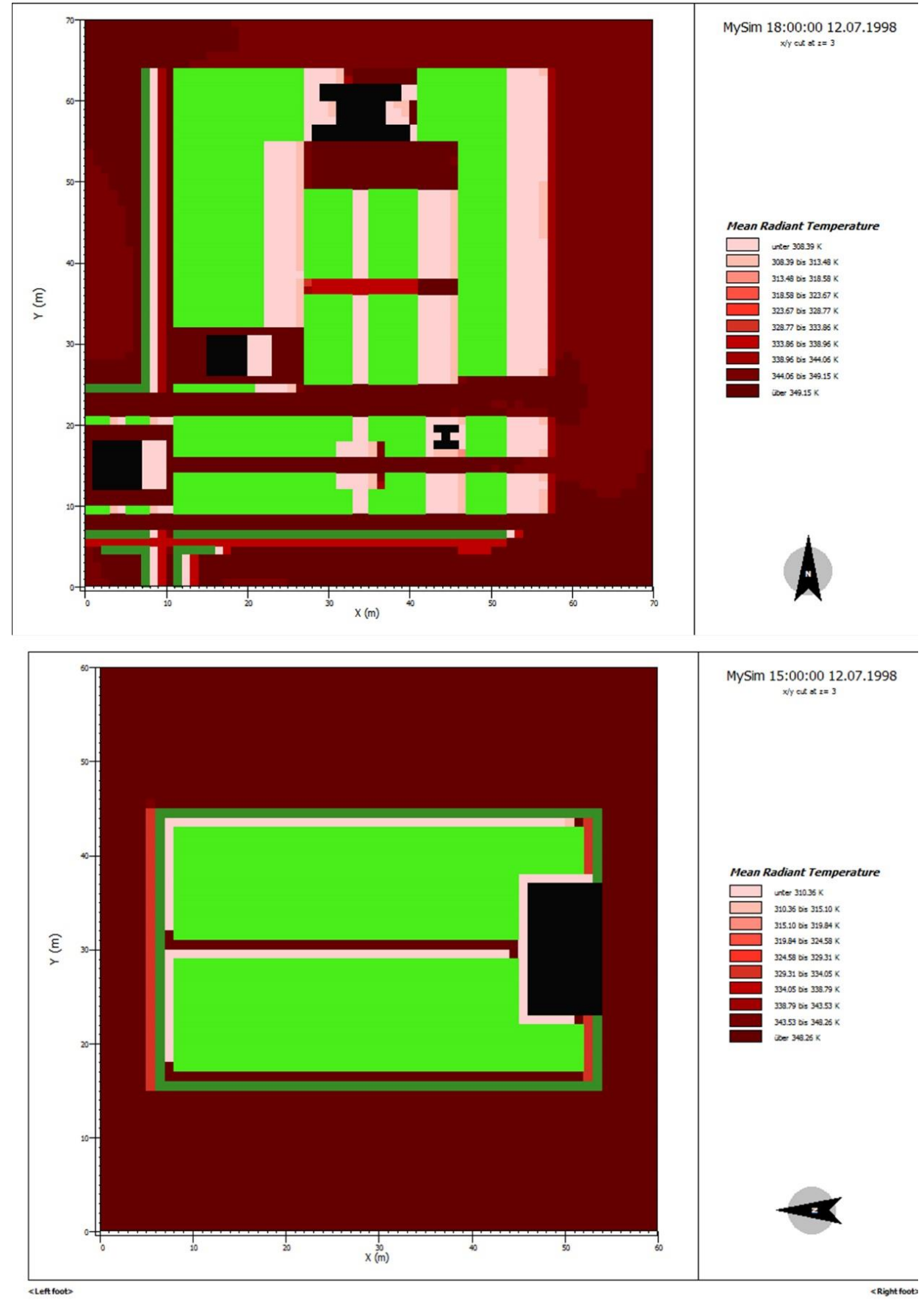

Regarding the wind effect on thermal comfort especially in green space context, wind speed average is described in Table.7. 


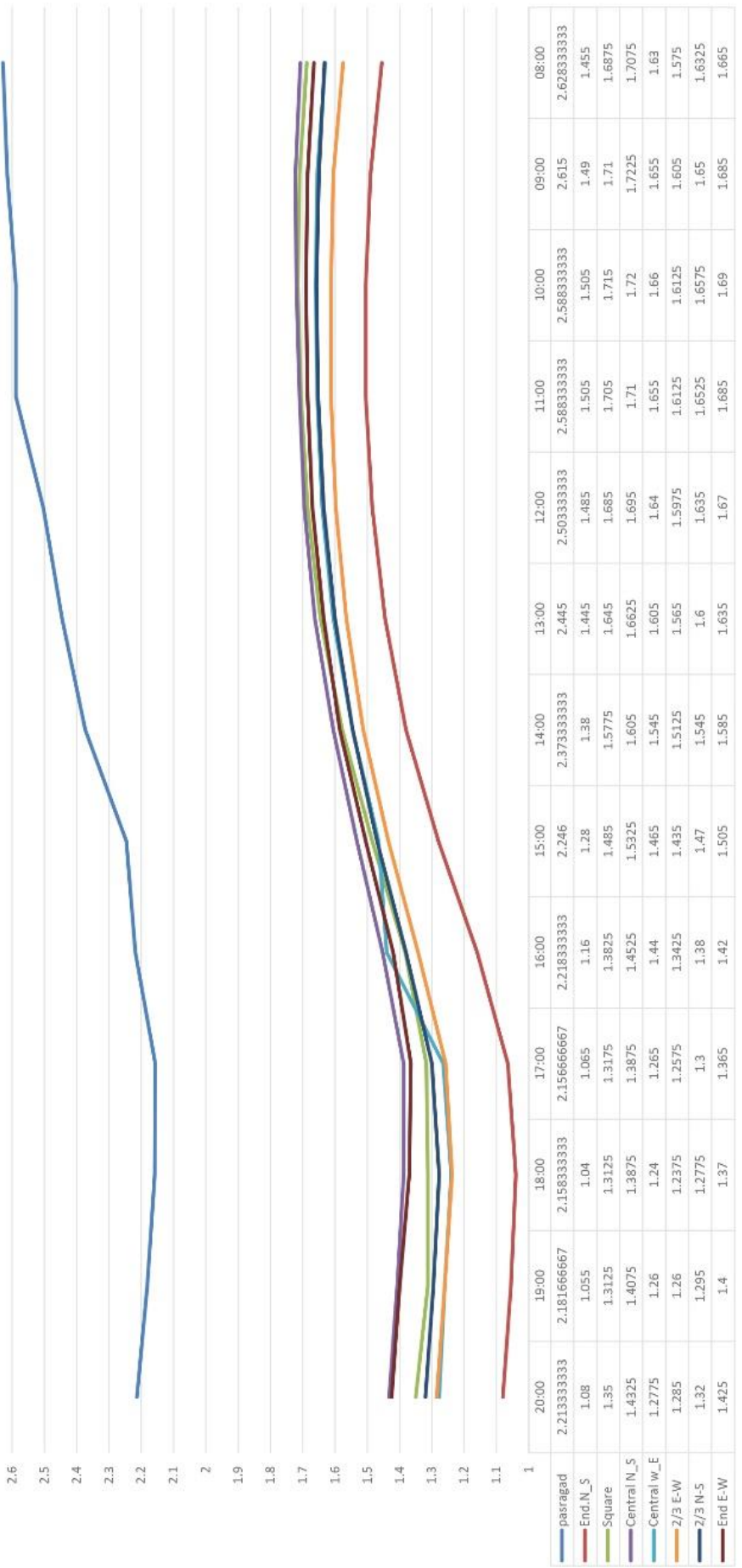

하릴 
The prevailing wind direction on this specific day is North-West $\left(315^{\circ}\right)$. According to the results (Fig.20) and with the comparing the patterns, the Pasargadae pattern has the highest wind velocity and the End-N-S pattern has the lowest one.

Table 6: Microclimate average data of patterns

\begin{tabular}{|c|c|c|c|c|c|c|c|c|}
\hline & square & end.N-S & end.E-W & $2.3 . \mathrm{N}-\mathrm{S}$ & $2.3 . \mathrm{E}-\mathrm{W}$ & center.N-S & center.E-W & pasargad \\
\hline wind-speed & 1.515 & 1.285 & 1.535 & 1.4775 & 1.49 & 1.56 & 1.47 & 2.366667 \\
\hline air temperature & 301.335 & 301.65 & 301.66 & 301.7975 & 301.795 & 301.6975 & 301.755 & 301.6733 \\
\hline Tmrt & 328.8475 & 332.77 & 324.845 & 328.205 & 328.3225 & 329.6125 & 329.4225 & 340.4262 \\
\hline Average.of SVF & 0.782 & 0.77 & 0.77 & 0.7857 & 0.7857 & 0.7745 & 0.7745 & 0.933 \\
\hline
\end{tabular}

According to Fig 21, wind speed of rectangular patterns except for the End.N-S one, is about $1.5 \mathrm{~m} / \mathrm{s}$ and in the rectangular patterns the End.N-S has the lowest wind speed $(1.285 \mathrm{~m} / \mathrm{s})$ and the Centeral.N-S $(1.56 \mathrm{~m} / \mathrm{s})$ has the highest wind velocity. But the Pasargadae has the highest one with $2.36 \mathrm{~m} / \mathrm{s}$ velocity. In this regard, to evaluate the wind behavior in these two patterns, open spaces and orientation should be considered. Previously $\mathrm{SVF}^{2}$ and its relation to open spaces have been discussed, in other words, the environments with wider open spaces are more prone to have higher wind velocity. Hereby the correlation of the $\mathrm{SVF}^{2}$ and wind speed has been calculated by the Pearson coefficient in SPSS software. $\mathrm{R}$-value of $\mathrm{SVF}^{2}$ and the wind speed in Pasargadae is 0.8719. It shows high enough correlation between wide open spaces and wind velocity.

Fig. 21: Average of wind speed of the patterns

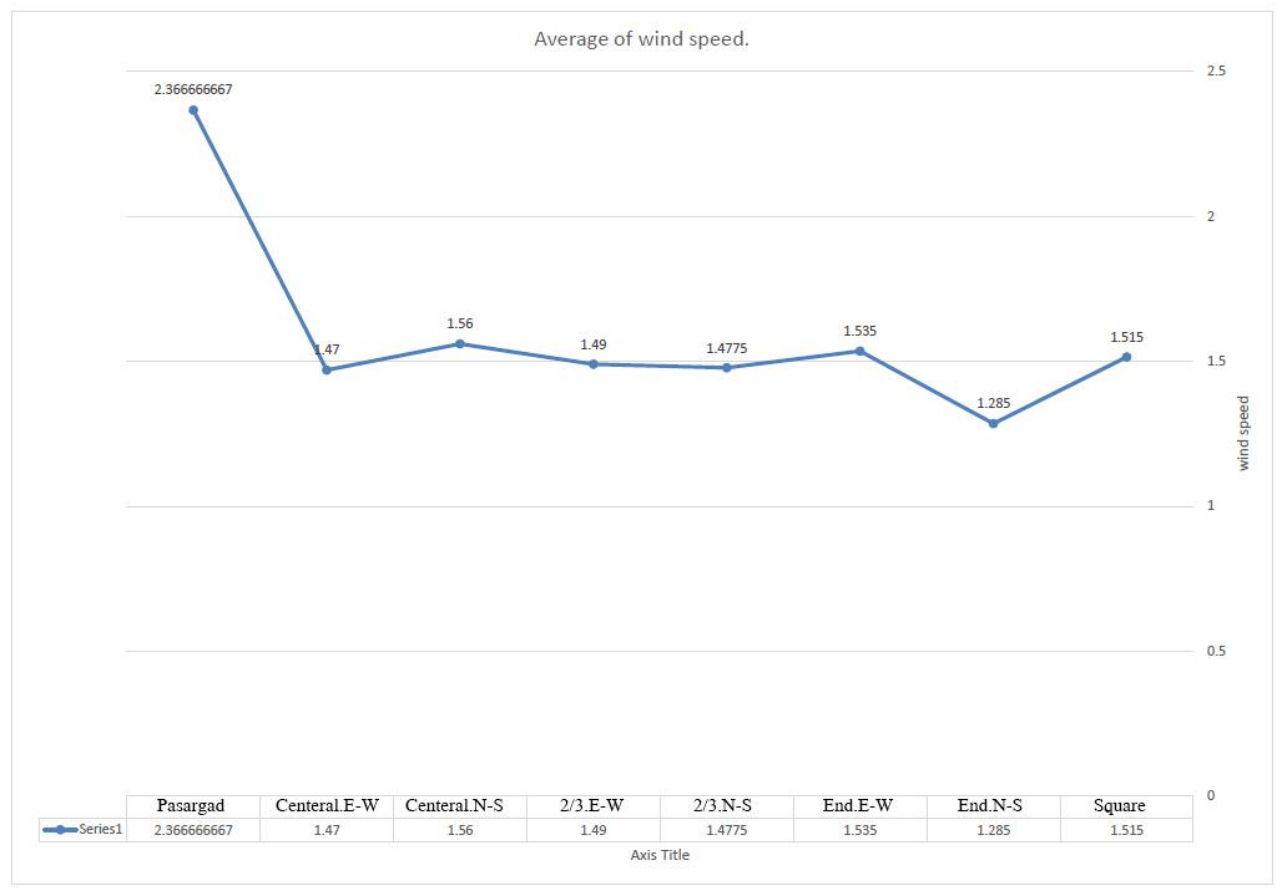


Ojaghlou M., Khakzand M.: Thermal comfort characteristic of 5 patterns of a Persian garden in a hot-arid climate of Shiraz. Iran

In terms of orientation, due to the North-West prevailing wind, the main path of the End pattern garden with North-South orientation is sufficiently sheltered by both trees and pavilion. In all other conditions except the Ends one, due to the rear road of the pavilion, receptors are exposed to the prevailing local wind. Hourly frequency of both Pasargadae and the End.N-W patterns are described by the Fig. 22.

\section{Fig. 22: Wind hourly frequency of Pasargadae and End.N-S}

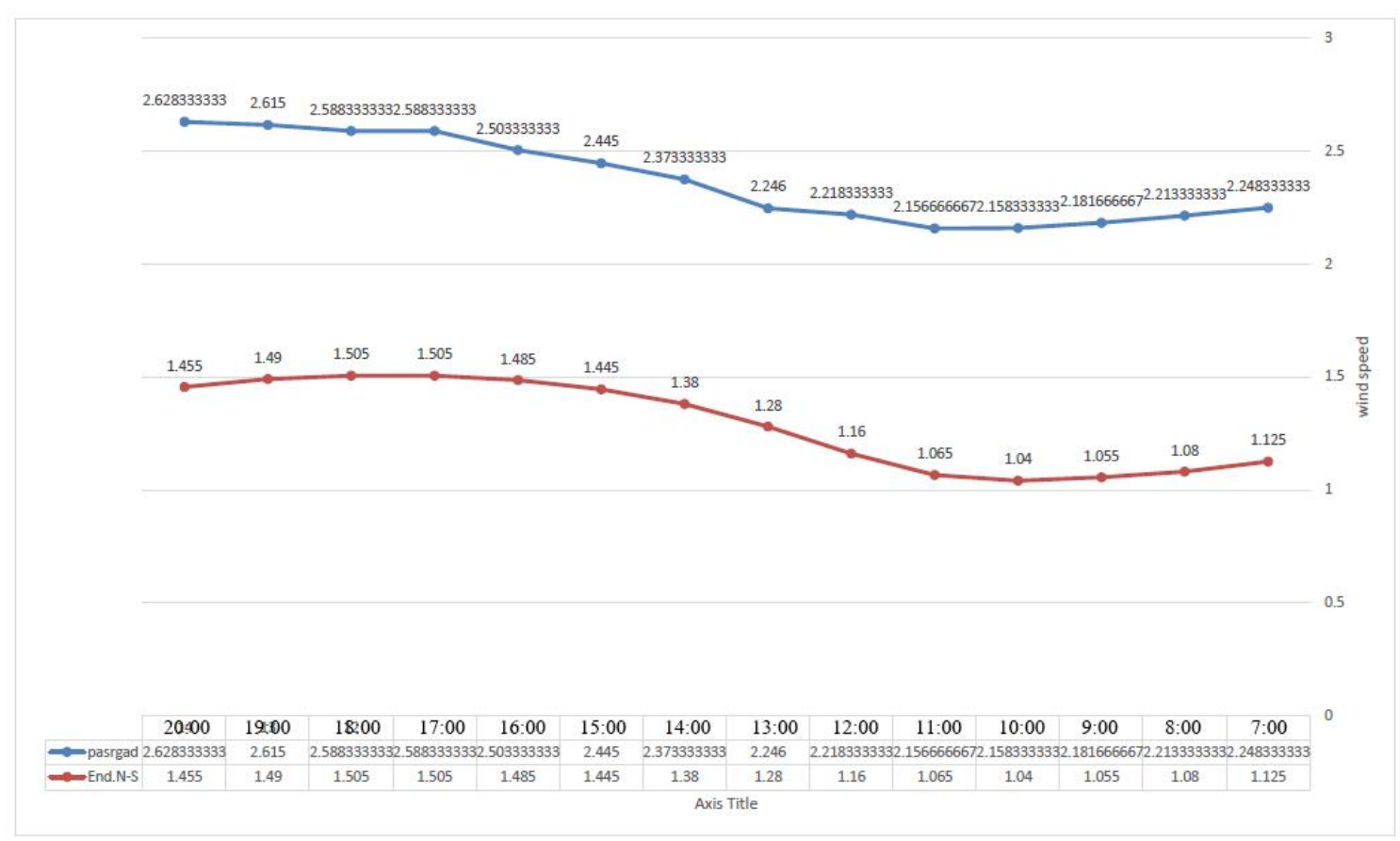

The behavior of both patterns is the same in the wind frequency condition. It means that the minimum of both patterns happens at 11:00 and the maximum happen at 17:00. However, the changes in End.N-S occurs more smoothly than the Pasargadae pattern.

In this study, the thermal comfort of the Persian garden has been evaluated by its different patterns in 8 conditions. In this regard, the PET $^{1}$ thermal comfort index has been chosen for comfort evaluation. Therefore, the $\mathrm{PET}^{1}$ value has been calculated at different points of the paths (in the first, middle and at the end of each path) on the hottest day in Shiraz. Hourly frequency of the PET $^{1}$ value for each pattern has been illustrated in Fig.23. PET ${ }^{1}$ value highly depends on $\mathrm{Tmrt}^{7}$ and has a direct effect on the thermal comfort condition (Matzarakis et al., 1999; Matzarakis et al., 2008; Thorsson et al., 2004). Also, R-values of all patterns represent more than $93 \%$ correlation between the $\mathrm{Tmrt}^{7}$ and $\mathrm{PET}^{1}$ in these gardens. 


\section{Fig. 23: Hourly frequency of PET of the patterns}

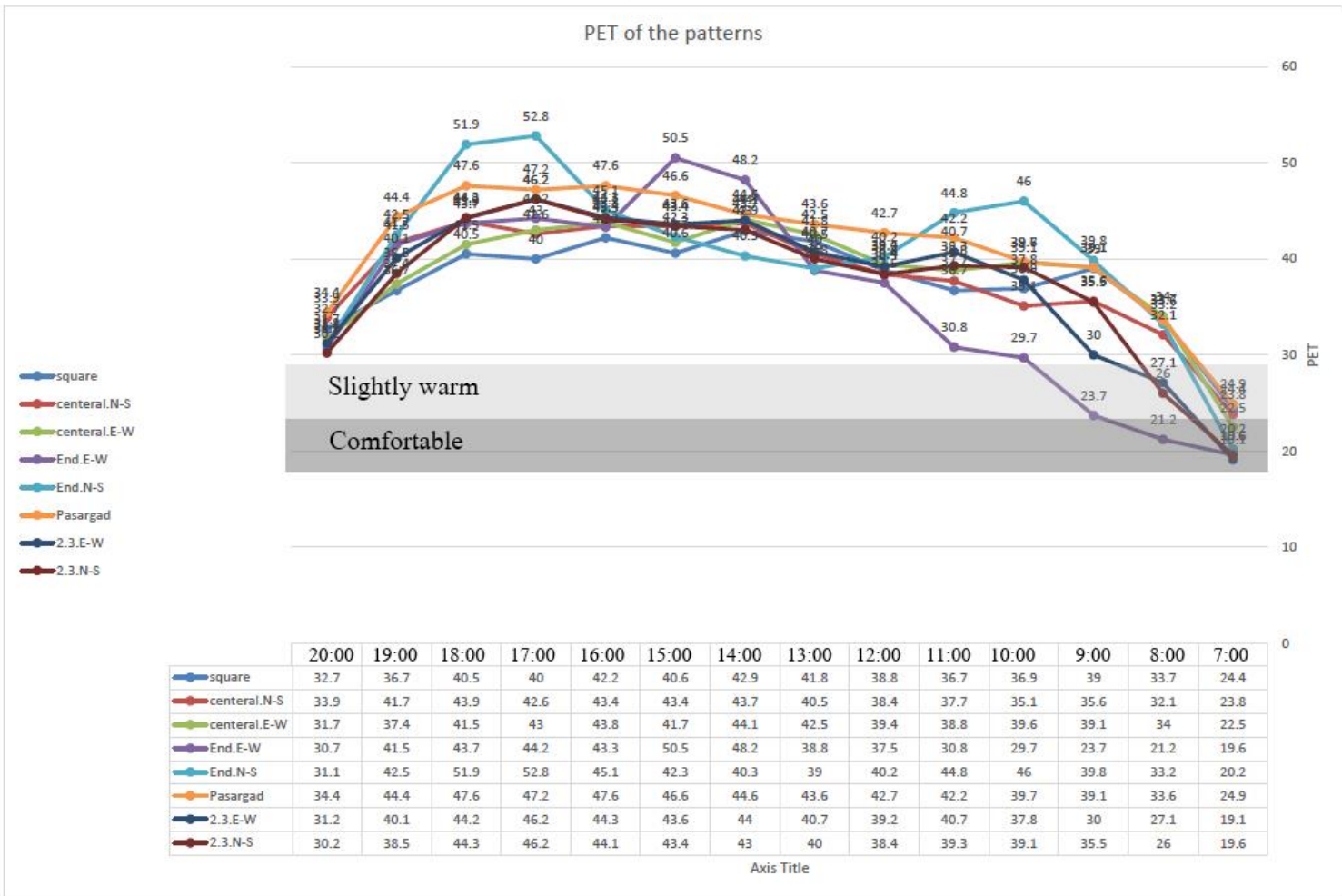

Based on the results, during the mentioned day, the average of the $\mathrm{PET}^{1}$ value for the located receptors shows that the End.E-W pattern has the lowest amount of the PET ${ }^{1}$ among the patterns. In Fig.24 the slightly cool and slightly warm comfort levels, are highlighted by a gray coverage. As formerly indicated, all the patterns at the beginning of the morning are in the comfort range. But the behavior of the patterns is different from the passage of time. Except for the End.E-W, Two, Third.N-S and E-W patterns, other patterns move quickly to the uncomfortable range. According to mean radiant temperature, the End.E-w pattern has the best condition in the $\mathrm{PET}^{1}$ analysis, and its related diagram takes more time ( 3 hours) to go to the uncomfortable area and in contrast, the Pasargadae, square, and the central .N-S patterns have no points in comfortable range. By reaching the first rays of sun their $\mathrm{PET}^{1}$ values start to move to the uncomfortable range, it means that these patterns are in the slightly warm area just for 30 minutes. However, all of the patterns have a high amount of $\mathrm{PET}^{1}$ in the afternoon. After 14:00, the square pattern has the lowest PET ${ }^{1}$ till 19:00, and by the end of the day, the Two.third N-S pattern reaches the lowest PET $^{1}$ among the patterns and at 17:00 the End .N-S reaches the highest PET ${ }^{1}$ among the models. But on the average, the End E-W pattern has still the lowest and the best condition of PET $^{1}$ value. 
Ojaghlou M., Khakzand M.: Thermal comfort characteristic of 5 patterns of a Persian garden in a hot-arid climate of Shiraz. Iran

\section{Fig. 24: Average of PET for the patterns}

\section{Average of PET values.}

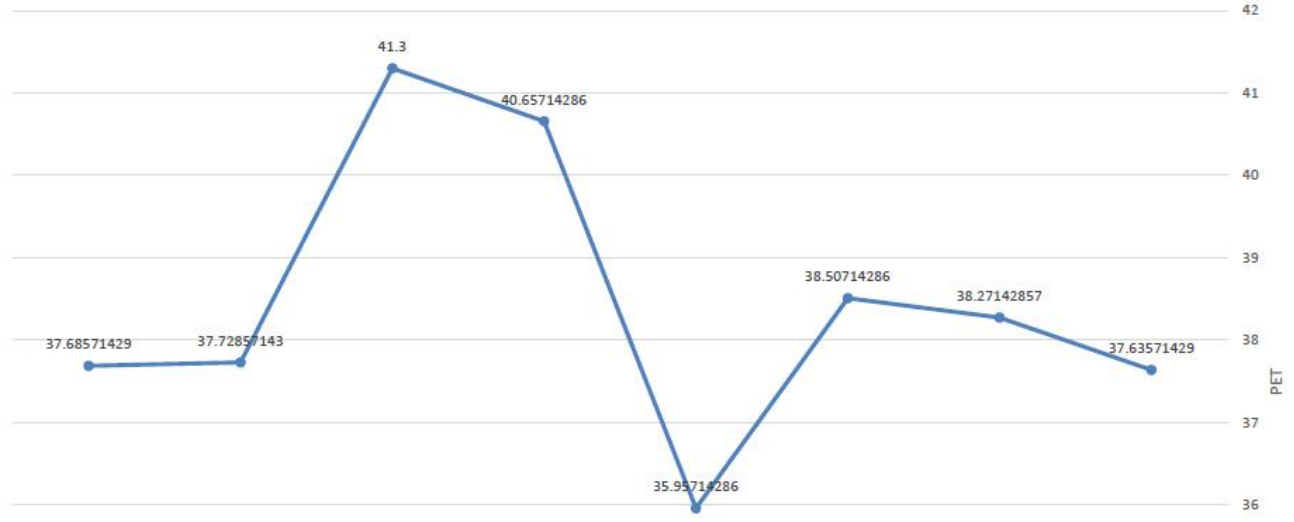

\begin{tabular}{|c|c|c|c|c|c|c|c|}
\hline two.third.N-S & two.third.E-W & Pasargad pattern & End.N-Spattern & End.E-Wpattern & centeral.E-Wpattern & centeral.N-Spattem & square pattern \\
\hline 37.68571429 & 37.72857143 & 41.3 & 40.65714286 & 35.95714286 & 38.50714286 & 38.27142857 & 37.63571429 \\
\hline
\end{tabular}

\section{CONCLUSIONS}

Persian garden is one of the main concepts of landscape architecture in relation to form and meaning. This concept is common, especially in Middle East countries and also in Iran. These gardens have been investigated in various ways, but have been rarely studied by considering its microclimatic features. A comparison study of the garden forms as the pattern of designing can leads the designers to make the environments more thermally comfortable. In this regard, three general forms of gardening in Shiraz were selected: rectangular gardens, square gardens, and Pasargadae garden as an ancient pattern. Consequently, all conditions of these forms based on their real example garden in Shiraz in 8 conditions were simulated by the ENVI-met3.1 model. Modified Shadow and wind comfort is the most important microclimatic features of a Persian garden, therefore mean radiant temperature and wind velocity are more affected by the garden's different patterns. The findings of this study showed that in the hot and arid climate of Shiraz rectangular form with the pavilion located at the end of the garden by correct orientation can reach the best condition of mean radiant temperature conversely this pattern by 90 degrees rotation reached the highest amount of Tmrt. But in general comparison, the Pasargadae pattern has the highest Tmrt among all patterns. In the rectangular and square patterns due to the limited Sky View Factor, the mean radiant temperature has no correlation with the air temperature, it means that the maximum of the Tmrt doesn't occur at the same time of the maximum of air temperature but in Pasargadae pattern because of the different orientation of the paths and also high $\mathrm{SVF}^{2}$ value there is high enough correlation between the air temperature, $\mathrm{Tmrt}^{7}$, short wave radiation both indirect and 
diffuse condition, it means that the maximum of the Tmrt ${ }^{7}, \mathrm{Ta}^{8}, \mathrm{SW} \cdot \mathrm{dir}^{14}$, SW.diff ${ }^{15}$ happen in short intervals and also this means that controlling the environmental parameters in this kind of garden is more difficult than the other patterns.

Because of the prevailing wind of Shiraz in the reference day (North-west), the End.N-S patterns has the lowest wind velocity, and also due to N-S orientation of the path, green spaces are located in west side and pavilion is located in north of garden, so this condition helps the receptors to reach the lowest wind speed. In contrast, the wind in the Pasargadae pattern by having a different orientation of paths and wider paths has more opportunity to get more speed and the correlation of $\mathrm{SVF}^{2}$ and wind speed has been shown by 0.87 of R-value.

Consequently, the $\mathrm{PET}^{1}$ values of the patterns are calculated by the Rayman model. As expected, the PET value is dependent on Tmrt, so the hourly PET $^{1}$ of the patterns changes by the Tmrt manner which means that maximum of the $\mathrm{PET}^{1}$ occurs in the Tmrt maximum. Therefore, the End.E-W pattern has the best condition in terms of PET thermal index, the Pasargadae has the worst one, and in the rectangular patterns, the End.N-S pattern has the highest $\mathrm{PET}^{1}$ value.

Finally, this study recommends the end.E-W pattern as the optimum pattern for designing more comfortable parks and open green spaces with Persian garden concept. But the Persian garden needs more and more researchers in microclimate field in different context and cities, especially in Iran. Since there is a wide range of climatic diversity in Iran, Persian garden has different roles in different climates. So these gardens need further investigation in thermal comfort and microclimatic field because the basic mission of the Persian garden is to transform the rough environment into tolerable thermal comfort condition.

PS:

1-Physiological Equivalent temperature (PET)

2- Sky view factors (SVF)

3-Leaf Area Density (LAD)

4- Leaf Area Index (LAI)

5-Standard Effective Temperature (SET)

6-Predicted Mean Vote (PMV)

7-Mean Radiant Temperature (Tmrt)

8- Air temperature (Ta)

9- Metabolic rate $(\mathrm{M})$

10- Physical work output (R)

11- Net radiation of the body $(\mathrm{C})$

12-Universal Thermal Climate Index (UTCI)

13-corrected modified effective temperature

14- Shortwave Direct Radiation (SW direct)

15- Shortwave Diffuse Radiation (SW diffuse)

\section{REFERENCES}

Ambros, Z. (1978). Water balance of forest stands in the Carpathians (in Slovak). Lesnictvi-Forestry 24: 203-221.

Ahn, Y. S., Ryu, S. R., Lim, J., Lee, C. H., Shin, J. H., Choi, W. I., \& Seo, J. I. (2014). Effects of forest fires on forest ecosystems in eastern coastal areas of Korea and an overview of restoration projects. Landscape and ecological engineering, 10(1), 229-237.

Akbari, Y. W. U. B. H. (2015). Comparing the effects of Urban Heat Island Mitigation. Journal of molecular biology, 342(1), 131-143.

Alexandri, E, Jones, P. (2008). Temperature decreases in an urban canyon due to green walls 
Ojaghlou M., Khakzand M.: Thermal comfort characteristic of 5 patterns of a Persian garden in a hot-arid climate of Shiraz. Iran

and green roofs in diverse climates. Building and Environment, 43: 480-493.

Ali-Toudert, F. (2007). Mayer FH. Effects of asymmetry, galleries, overhanging facades and vegetation on thermal comfort in urban street canyons. Sol Energy; 81:742e54.

Andreou, E. (2013). Thermal comfort in outdoor spaces and urban canyon microclimate. Renew Energy; 55:182e8.

Andreou, E. (2013). Thermal comfort in outdoor spaces and urban canyon microclimate. Renewable energy, 55, 182-188.

ASHRAE Standard 55-56 (1966). Thermal comfort conditions. American society of heating refrigerating and air- conditioning engineers, New York.

Ashrae (2001). Ashrae Fundamentals. Handbook 2001; Atlanta, Ga., American Society of Heating, Refrigerating, and Air-Conditioning Engineers.

Balafoutis, C.H., Arseni-Papadimitriou, A., Chantzaridis, P. (1998). Distribution of thermal comfort during June at Greek Land. In: Proceedings: 4 the Panhellenic Geographical Conference at 12, 13, 14 October 1995 (pp. 440-450). Greek Geographical Union.

Bateson, M. C. (1993). Joint performance across cultures: Improvisation in a Persian garden.

Behzadfar, M, \& Monam, A. (2011). The impact of sky view factor on outdoor thermal comfort. Armanshahr, 5 23-34.

Benmanian, M.R, Taghvaei, A.A, Shahidi, M.SH. (2008). Evaluation of environmental and cultural foundations Garden physical elements of Iran (before and after Islam), Journal of Environment Science and Technology. NO.1, pp103-112.

Benzinger, T.H. (1979). The physiological basis for thermal comfort, Indoor climate. Danish building research institute, Copenhagen. Pp.441-476.

Blaxejczyk, K., Broede, P, Fiala, D, Havenith, G, Holmer, I, Jendritzky, G., Kampmann, B. \& Kunert, A. (2010). Principles of the new Universal Thermal Climate Index (UTCI) and its application to bioclimatic research in European scale. Miscellanea Geographica, 14.pp 91-102.

Bouyer, J., Vinet, J., Delpech, P., Carré, S. (2007). Thermal comfort assessment in semi-outdoor environments: application to comfort study in stadia. Journal of Wind Engineering and Industrial Aerodynamics, 95: 144-149.

Brown, R. D. (1995). Microclimatic landscape design: Creating thermal comfort and energy efficiency. New York: Wiley.

Bruse, M. (2012). ENVI-met. Michael Bruse, Essen.

Bruse, M., Fleer, H., (1998). Simulating surface-plant-air interactions inside urban environments with a three dimensional numerical model. Environmental modelling \& software, 13(3-4), pp.373-384.

Bruse, M., (2009). June. Analysing human outdoor thermal comfort and open space usage with the Multi-Agent System BOTworld. In Seventh International Conference on Urban Climate ICUC-7 (Vol. 29).

Burckhardt, T. (1976). Art of Islam.

Byomkesh, T., Nakagoshi, N., \& Dewan, A. M. (2012). Urbanization and green space dynamics in Greater Dhaka, Bangladesh. Landscape and Ecological Engineering, 8(1), 45-58.

Byrne, B., Coventry, W.L., Olson, R.K., Samuelsson, S., Corley, R., Willcutt, E.G., Wadsworth, S. and DeFries, J.C., (2009). Genetic and environmental influences on aspects of literacy and language in early childhood: Continuity and change from preschool to Grade 2. Journal of Neurolinguistics, 22(3), pp.219-236. 
Čermák, V., Šafanda, J. and Guterch, A., (1989). Deep temperature distribution along three profiles crossing the Teisseyre-Tornquist tectonic zone in Poland. Tectonophysics, 164(2-4), pp.151-163.

Chang, C-R., Li, M-H., Chang, S-D. (2007). A preliminary study on the local cool-island intensity of Taipeicityparks. Landsc.Urban.Plan.;80:386-95.

Chen, L., Ng, E. (2012). Outdoor thermal comfort and outdoor activities: a review of research in the past decade. Cities; 29:118e25.

Chen, Y., Wong, N.H. (2006). Thermal benefits of city parks. Energy Build; 38: 105e20.

Chou, W. Y., Lee, C. H., \& Chang, C. Y. (2016). Relationships between urban open spaces and humans' health benefits from an ecological perspective: a study in an urban campus. Landscape and Ecological Engineering, 12(2), 255-267.

Cohen, P., Potchter, O., Matzarakis, A. (2013). Human thermal perception of Coastal Mediterranean outdoor urban environments. Appl Geogr; 37:1e10.

d'Ambrosio Alfano, F.R., Palella, B.I., Riccio, G. (2011). Thermal environment assessment reliability using temperature-humidity indices. Ind Health; 49:95e106.

Das, D. (2008). Urban Quality of Life: A Case Study of Guwahati, Springer Science+Business Media B.V., Soc Indic Res 88:297-310.

Dessi, V. (2002). People's behaviour in an open space as design indicator. Paper presented at the International Conference on Pasive and Low Energy Architecture PLEA, Toulouse, France.

Dimoudi, A., Kantzioura, A., Zoras, S., Pallas, C., \& Kosmopoulos, P. (2013). Investigation of urban microclimate parameters in an urban center. Energy and Buildings, 64, 1-9.

Do, Y., Kim, J. Y., Kim, G. Y., \& Joo, G. J. (2014). Importance of closed landfills as green space in urbanized areas: ecological assessment using carabid beetles. Landscape and ecological engineering, 10(2), 277-284.

Fanger, P.O (1972). Thermal Comfort: Analysis and applications in environmental engineerin. New York, McGraw Hill.

Ghodarzi Soroush, M.M, Mokhtabaad, S.M. (2013). Symbolism in Persian garden in Islamic Period. Journal Hoviat-e-Shahr, No13, pp55-62.

Givoni, B. (1998). Climate Considerations in Building and Urban Design. Van Nostrand Reinhold, New York.

Givoni, B. (1976). Man, Climate and Architectur. London. Applied Science Publishers.

Gulyás, A., Unger, J, Matzarakis, A. (2006). Assessment of the microclimatic and human comfort conditions in a complex urban environment: Modelling and measurements. Building and Environment, 41: 1713-1722.

Heijs, W. (1994). The dependent variable in thermal comfort research: some psychological considerations, Thermal Comfort: Past, Present and Future. In Proceedings of a conference held at the Building Research Establishment, Garston, 9-10 June 1993 (pp. 40-51).

Hensen, J. L. M. (1990). Literature review on thermal comfort in transient conditions, Building and Environment: 25 no. 4, pp. 309 - 316.

Herrmann, J, Matzarakis, A. (2012). Mean radiant temperature in idealised urban canyonsdexamples from Freiburg, Germany. Int J Biometeorol; 56:199e203.

Hodder, S. G, Parsons, K. (2007). The effects of solar radiation on thermal comfort. Int. J. Biometeorol, 51: 233-250.

Hofman, J., Bartholomeus, H., Janssen, S., Calders, K., Wuyts, K., Van Wittenberghe, S., \& 
Ojaghlou M., Khakzand M.: Thermal comfort characteristic of 5 patterns of a Persian garden in a hot-arid climate of Shiraz. Iran

Samson, R. (2016). Influence of tree crown characteristics on the local PM10 distribution inside an urban street canyon in Antwerp (Belgium): A model and experimental approach. Urban forestry \& urban greening, 20: 265-276.

Höppe, P. (1999). The physiological equivalent temperature - a universal index for the bio meteorological assessment of the thermal environment. Int. J. Biometeoroi, 43: 71-75.

Huttner, S., Bruse, M., \& Dostal, P. (2008, October). Using ENVI-met to simulate the impact of global warming on the microclimate in central European cities. In 5th Japanese-German Meeting on Urban Climatology Vol. 18 (pp. 307-312).

Hwang, R. L., Lin, T. P. \& Matzarakis, A. (2011). Seasonal effects of urban street shading on long-term outdoor thermal comfort. Building and environment, 46(4), 863-870.

ISO (1984). International Standard 7730. ISO Geneva, revised 1990.

Jendritzky, G. and W. Nübler. (1981). A model analysing the urban thermal environment in physiologically significant terms. Meteorology and Atmospheric Physics, 29: 313-326.

Jim, C. Y. (2012). Effect of vegetation biomass structure on thermal performance of tropical green roof. Landscape and ecological engineering, 8(2), 173-187.

Joffre, R., Rambal, S., (1993). How tree cover influences the water balance of Mediterranean rangelands. Ecology, 74(2), pp.570-582.

Johansson, E. (2006). Influence of urban geometry on outdoor thermal comfort in a hot dry climate: a study in Fez, Morocco. Build Environ; 41:1326e38.

Katouzian, S. (1986). The Sense of Place in Persian Gardens.

Kim, J. O., \& Suh, J. H. (2016). A review of climate change adaptation policies applied to landscape planning and design in Korea. Landscape and Ecological Engineering, 12(1), 171-177.

Kinouchi, T. (2001). A study on thermal indices for the outdoor environment. Tenki, 48: 661-671.

K.P., Nastos, P.T., Paliatsos, A.G. (2013). One-day prediction of biometeorological conditions in a mediterranean urban environment using artificial neural networks modeling. Adv Meteorol; 2013:1e15.

Kurazumi, Y., Fukagawa, K., Yamato, Y., Tobita, K., Kondo, E., Tsuchikawa, T., Horikoshi, T. \& M., Naoki (2011). Enhanced conduction-corrected modified effective temperature as the outdoor thermal environment evaluation index upon the human body; Building and Environment, 46: Pp12-21.

La Rosa, D., \& Privitera, R. (2013). Characterization of non-urbanized areas for land-use planning of agricultural and green infrastructure in urban contexts. Landscape and Urban Planning, 109(1), 94-106.

Lee, S. H., Lee, K. S., Jin, W. C., \& Song, H. K. (2009). Effect of an urban park on air temperature differences in a central business district area. Landscape and Ecological Engineering, 5(2), 183-191.

Li, R, Chi, X. (2013). Thermal comfort and tourism climate changes in the QinghaieTibet Plateau in the last 50 years. Theor Appl Climatol. DOI: http:// dx.doi.org/10.1007/s007 04-013-1027-5.

Limb, M. (1992). Technical notes-an infiltration and ventilation glossary Air infiltration and ventilation center. $\mathrm{p} 36$.

Mahmoudi Farahani, L., Motamed, B., Jamei, L. (2016). Persian Gardens: Meanings, 
Symbolism, and Design. Landscape Online 46:1-19.

Maleki, A., Orehounig, K., \& Mahdavi, A. (2013). Monitoring and modeling of the urban micro-climate. International Conference on Architecture and Urban Design.

Matzarakis, A., Amelung, B. (2008). Physiological equivalent temperature as indicator for impacts of climate change on thermal comfort of humans. In: Thomson M.C., García Herrera R., Beniston M., editors. Seasonal forecasts, climatic change and human health (pp :1-99).

Matzarakis, A., Mayer, H. (1997). Heat stress in Greece. International Journal of Biometeorology, 41: 34-39.

Matzarakis, A., \& Amelung, B. (2008). Physiological equivalent temperature as indicator for impacts of climate change on thermal comfort of humans. In Seasonal forecasts, climatic change and human health (pp. 161-172). Springer Netherlands.

Matzarakis, A., Mayer, H., \& Iziomon, M. G. (1999). Applications of a universal thermal index: physiological equivalent temperature. International Journal of Biometeorology, 43(2), 76-84.

Matzarakis, A., Rutz, F., Mayer, H. (2007). Modelling radiation fluxes in simple and complex environments - application of the RayMan model, Int. J. Biometeorol, 51: 323-334.

McIntyre, D.A. (1980). Indoor climate. Applied science publishers, London, p 56.

Medghalchi, L., Ansary, M., Benmaniam, M.R. (2014). Sense of place in Persian garden. Journal of Bagh e Nazar, No 28, pp 25-38.

Middel, A., Häb, K., Brazel, A. J., Martin, C. A., \& Guhathakurta, S. (2014). Impact of urban form and design on midafternoon microclimate in Phoenix Local Climate Zones. Landscape and Urban Planning, 122, 16-28.

Moghtader, M.R.,Yavari, M. (1998). The Persian Garden: Eshoes of paradise, International conference of Persian garden.

Müller, N., \& Morimoto, Y. (2016). Landscape Design and Urban Biodiversity. Landscape and Ecological Engineering, 12(1), 105-106.

Naeema, Gh. (2006). Persian gardens. Payam publication, Tehran. Iran.

Nagano, K. \& Horikoshi, T. (2011). New index indicating the universal and separate effects on human comfort under outdoor and non-uniform thermal conditions; Energy and Buildings, 43: pp 1694-1701.

Nastos, P.T., Matzarakis, A. (2012). The effect of air temperature and human thermal indices on mortality in Athens, Greece. Theor Appl Climatol; 108:591e9. DOI: http://dx.doi.org/10.1007/s00704-011-0555-0.

Nichol, J., Wong, M.S. (2005). Modelling urban environmental quality in a tropical city. Lansdcape and Urban Planning; 75:49-58.

Oke, T.R. (1987). Boundary layer climates. New York: Routledge.

Olgyay, V. (1963). Design with climate. Princeton university press, Princeton, New Jersey.

Oliveira, S., Andrade, H. and Vaz, T., (2011). The cooling effect of green spaces as a contribution to the mitigation of urban heat: A case study in Lisbon. Building and environment, 46(11), pp.2186-2194.

Orsini, F., Gasperi, D., Marchetti, L., Piovene, C., Draghetti, S., Ramazzotti, S. \& Gianquinto, G. (2014). Exploring the production capacity of rooftop gardens (RTGs) in urban agriculture: the potential impact on food and nutrition security, biodiversity and other ecosystem services in the city of Bologna. Food Security, 6(6), 781-792.

Peng, L. L., \& Jim, C. Y. (2013). Green-roof effects on neighborhood microclimate and human 
Ojaghlou M., Khakzand M.: Thermal comfort characteristic of 5 patterns of a Persian garden in a hot-arid climate of Shiraz. Iran

thermal sensation. Energies, 6(2), 598-618.

Penka, M., Cermák, J., Stepanek, V. and Palat, M., (1979). Diurnal courses of transpiration rate and transpiration flow rate as determined by the gravimetric and thermometric methods in a full-grown oak tree (Quercus robur L.). Acta Universitatis Agriculturae. Ser. C. Facultas Silviculturae. Brno.

Pickup, J. and R.D. Dear (1999). An outdoor thermal comfort Index (OUT-SET*). 15th ICB \& ICUC, Macquarie University, Sydney.

Pielke, R. A. (1984). Mesoscale meteorological modelling, Academic Press, Orlando.

Pirniya, M.K. (1994). Interview with Abadi magazine.

Pourvahidi, P., \& Ozdeniz, M. B. (2013). Bioclimatic analysis of Iranian climate for energy conservation in architecture. Scientific Research and Essays, 8(1), 6-16.

Qaid, A., Ossen, D.R. (2014). Effect of asymmetrical street aspect ratios on microclimates in hot, humid regions. Int J Biometeorol.

Ranjbar Kermani, A.A. (2005). Class notes of the Iranian architecture class. Spring of 2005.

Salata, F., Golasi, I., de Lieto Vollaro, A., \& de Lieto Vollaro, R. (2015). How high albedo and traditional buildings' materials and vegetation affect the quality of urban microclimate. A case study. Energy and Buildings, 99, 32-49.

Setaih, K., Hamza, N., Townshend, T. (2013). Assessment of outdoor thermal comfort in urban microclimate in hot arid areas. In: $13^{\text {th }}$ International Conference of International Building Performance Sim- ulation Association (pp. 1-99), Chambery, France.

Skelhorn, C. P., Levermore, G., \& Lindley, S. J. (2016). Impacts on cooling energy consumption due to the UHI and vegetation changes in Manchester, UK. Energy and Buildings, 122, 150-159.

Soltan Zadeh, H. (1999). From four vault to four garden. The journal of architecture and culture (Memari \& Farhang). NO1.

Spronken-Smith R., Oke, T. (1998). The thermal regime of urban parks in two cities with different summer climates. IntJRemoteSens;19:2085-104.

Srivanit, M., Hokao, K. (2013). Evaluating the cooling effects of greening for improving the outdoor thermal environment at an institutional campus in the summer. Build Environ 2013; $66: 158 \mathrm{e} 72$.

Stronach, D. (1978). The Royal Garden Passargade: A Report on the Excavations. Oxford: British Institute.

Svensson, M. K., Thorsson S, Lindqvist. S. (2003). A geographical information system model for creating bioclimatic maps - examples from a high, mid-latitude city. International Journal of Biometeorology, 47: 102-112.

Taghvaei, S.H, Tahbaz, M., Motaghi Pisheh, S. (2015). The Role of Shade in Persian Garden, The Study of Thermal Comfort Conditions in Jahannama and Delgosha gardens. Journal of Iranian architecture studies. No.7.pp 35-56.

Taleghani, M., Kleerekoper, L., Tenpierik, M., van den Dobbelsteen, A. (2014). Outdoor thermal comfort within five different urban forms in the Netherlands. Build Environ" 73:138e50. DOI: http://dx.doi.org/10.1016/j.buildenv.2014.03.014

Taleghani, M., Sailor, D.J., Tenpierik, M., van den Dobbelsteen, A. (2014). Thermal assessment of heat mitigation strategies: the case of Portland State University, Oregon, USA. Build Environ; 73:138e50.

Taleghani, M., Tenpierik, M., Kurvers, S., van den Dobbelsteen, A. (2013). A review into 
thermal comfort in buildings. Renew Sustain Energy Rev;26:201e15.

Thorsson, S., Lindberg, F., Eliasson, I., \& Holmer, B. (2007). Different methods for estimating the mean radiant temperature in an outdoor urban setting. International Journal of Climatology, 27(14), 1983-1993.

Thorsson, S., Lindqvist, M., \& Lindqvist, S. (2004). Thermal bioclimatic conditions and patterns of behaviour in an urban park in Göteborg, Sweden. International Journal of Biometeorology, 48(3), 149-156.

Toparlar, Y., Blocken, B., Vos, P., van Heijst, G. J. F., Janssen, W. D., van Hooff, T. \& Timmermans, H. J. P. (2015). CFD simulation and validation of urban microclimate: A case study for Bergpolder Zuid, Rotterdam. Building and environment, 83, 79-90.

Tseliou, A., Tsiros, I.X., Lykoudis, S., Nikolopoulou, M. (2010). An evaluation of three biometeorological indices for human thermal comfort in urban outdoor areas under real climatic conditions. Build Environ;45:1346e52.

Tsilini, V., Papantoniou, S., Kolokotsa, D. D., \& Maria, E. A. (2015). Urban gardens as a solution to energy poverty and urban heat island. Sustainable Cities and Society, 14, 323-333.

Vasicek, O.A., (1980). A conditional law of large numbers. The Annals of Probability, pp.142-147.

VDI (1998). Methods for the human-biometerological assessment of climate and air hygiene for urban and regional planning. Part I: Climate, VDI guideline 3787. Part 2. Beuthen, Berlin.

Vouterakos, P.A., Moustris, K.P., Bartzokas, A., Ziomas, I.C., Nastos, P.T., Paliatsos, A.G. (2012). Forecasting the discomfort levels within the greater Athens area, Greece using artificial neural networks and multiple criteria analysis. Theor Appl Climatol, 110:329e43. DOI: http://dx.doi.org/10.1007/s00704-012-0626-X.

Vu, T.C., Asaeda, T., Eusuf, M.A. (1998). Reductions in air conditioning energy caused by a nearby park. Energy and Buildings, 29: 83-92.

Vyskot, M., (1975). K problematice jedle. Lesnicka prace.

Wania, A., Bruse, M., Blond, N., Weber, C. (2012). Analysing the influence of different street vegetation on traffic-induced particle dispersion using microscale simulations. J. Environ Manage; 94:91e101.

Wong, N.H., Jusuf, S.K., Win, A.L., Thu, H.K., Negara, T.S., Xuchao, W. (2007). Environmental study of the impact of greenery in an institutional campus in the tropics. Building and Environment; 42:2949e70.

Xia, T. Y., Wang, J. Y., Song, K., \& Da, L. J. (2014). Variations in air quality during rapid urbanization in Shanghai, China. Landscape and ecological engineering, 10(1), 181-190.

Yabe, K., \& Nakamura, T. (2010). Assessment of flora, plant communities, and hydrochemical conditions for adaptive management of a small artificial wetland made in a park of a cool-temperate city. Landscape and Ecological Engineering, 6(2), 201-210.

Yahia, M.W., Johansson, E. (2014). Landscape interventions in improving thermal comfort in the hot dry city of Damascus, Syria e the example of residential spaces with detached buildings. Landsc Urban Plan; 125:1e16.

Yamada, T. (1982). A numerical model study of turbulent airflow in and above a forest canopy, J. Met. Soc. Jap. 60:439-454.

Zarabadi, Z.S.S., Haeri, N., Larimian, T. (2011). Sense of place in the concept of Persian garden. International journal od academic reasearche.vol3.NO4.Part2. 